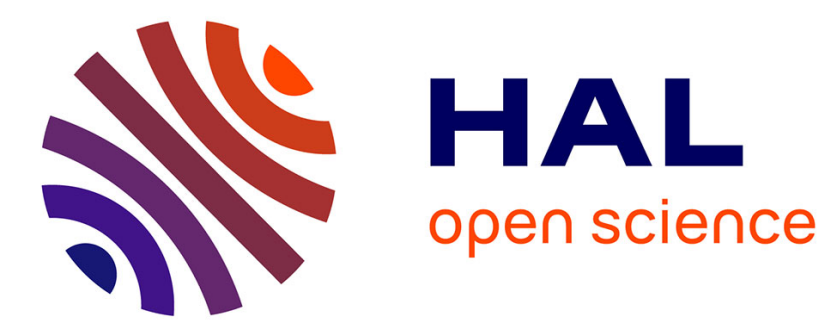

\title{
Enantioselective Indium-Catalyzed Transformations
}

Hélène Pellissier

\section{To cite this version:}

Hélène Pellissier. Enantioselective Indium-Catalyzed Transformations. Synthesis: Journal of Synthetic Organic Chemistry, 2021, 53 (8), pp.1379 - 1395. 10.1055/a-1348-9122 . hal-03205972

\section{HAL Id: hal-03205972 \\ https://hal.science/hal-03205972}

Submitted on 22 Apr 2021

HAL is a multi-disciplinary open access archive for the deposit and dissemination of scientific research documents, whether they are published or not. The documents may come from teaching and research institutions in France or abroad, or from public or private research centers.
L'archive ouverte pluridisciplinaire HAL, est destinée au dépôt et à la diffusion de documents scientifiques de niveau recherche, publiés ou non, émanant des établissements d'enseignement et de recherche français ou étrangers, des laboratoires publics ou privés. 


\section{Enantioselective Indium-Catalyzed Transformations}

\author{
Hélène Pellissier* (D) \\ Aix-Marseille Univ, CNRS, Centrale Marseille, iSm2, Marseille, \\ France \\ h.pellissier@univ-amu.fr
}
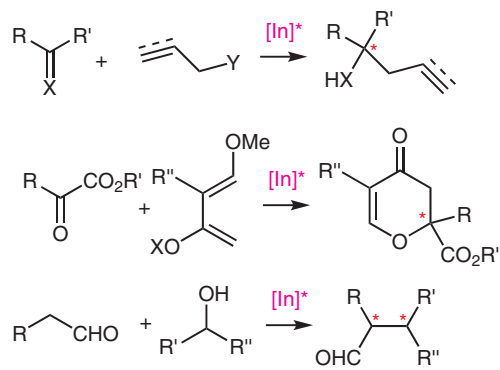

$\mathrm{A}+\mathrm{B} \stackrel{[\mathrm{In}]^{*}}{\longrightarrow}[\mathrm{C}]^{*} \longrightarrow \mathrm{D}^{*}$
Abstract This review updates the field of enantioselective indiumcatalyzed transformations of all types since 2012. It shows that asymmetric indium catalysis, that suits the growing demand for greener processes, offers a real opportunity to replace toxic metals in the near future.

2 Allylations, Propargylations, and Allenylations of Carbonyl Compounds and Derivatives

2.1 Allylations

2.2 Propargylations and Allenylations

Cycloadditions

3.1 Hetero-Diels-Alder Cycloadditions

3.2 1,3-Dipolar Cycloadditions

Miscellaneous Reactions

Domino and Tandem Reactions

Conclusion

Keywords asymmetric indium catalysis, enantioselective reactions, metal catalysis, chirality, asymmetric catalysis

\section{Introduction}

The traditional approach to catalysis using Lewis acids is changing rapidly from single-use, air- and moisture-sensitive metal complexes to less toxic, more stable, and more air- and water-tolerant catalysts, such as indium. More than a century after its discovery, indium, the chemistry of which remained for a long time limited to its use in semiconductors and other materials, was demonstrated to be able to mediate organic reactions, such as the Reformatsky reaction reported in 1975 by Rieke and Chao, ${ }^{1}$ and the allylation of carbonyl compounds reported in 1988 by Araki, Ito, and Butsugan. ${ }^{2}$ Since then, indium has emerged as a green metal of high potential in organic synthesis because of its unique properties. Especially in the last decade, a wide variety of highly enantioselective indium-catalyzed processes have been developed spanning from basic reactions, such as allylations, propargylations, and allenylations of carbonyl compounds and derivatives, cycloadditions, cyclizations, alkylations of aldehydes, aldol condensations, Michael additions, $S_{\mathrm{N}} 1$ reactions, etc., to more complex and modern processes, such as tandem and domino reactions through either carbon-carbon or carbon-heteroatom bond formation. Even if indium is a weaker Lewis acid than many transition metals, indium catalysis suits the growing demand for greener processes and offers a real opportunity to replace toxic metals in the near future. The goal of this review is to collect the major developments in enantioselective indium-catalyzed transformations published since 2012, since this field was most recently reviewed in 2013 by $\mathrm{Li}$ and $\mathrm{Xu}$ in a book chapter, covering the literature up to 2011. ${ }^{3}$ Previously, different reviews focusing on the general field of indium catalysis were published, ${ }^{4}$ along with others dealing with only racemic works. ${ }^{5}$ It must be noted that in 2016 a review on indium-mediated organic reactions was published by Yang, Wang, and Long, albeit with no asymmetric transformations. ${ }^{6}$ Moreover, reviews on organoindium reagents have to be mentioned. ${ }^{7}$ The present review is divided into four parts, dealing successively with enantioselective indium-catalyzed allylation/propargylation/allenylation reactions, cycloadditions, miscellaneous reactions, and tandem/domino reactions.

\section{Allylations, Propargylations, and Allenyla- tions of Carbonyl Compounds and Derivatives}

\subsection{Allylations}

Allylations of carbonyl compounds and derivatives such as imines, ${ }^{7 a, 8}$ constitute key steps in the synthesis of drug candidates, because both homoallylic alcohol and amine products are useful building blocks for the synthesis of bio- 
active heterocycles. In order to obtain these products enantiomerically pure, various chiral catalysts have been developed to promote allylations, among which are chiral indium complexes. ${ }^{9}$ The first enantioselective indium-mediated allylation reaction was reported in 1999 by Loh and coworkers, using a stoichiometric amount of (-)-cinchonidine as chiral ligand, which allowed enantioselectivities of up to $75 \%$ ee to be obtained. ${ }^{10}$ The first asymmetric allylation based on the use of a catalytic amount of chiral ligand was disclosed later in 2005 by Cook and co-workers. ${ }^{11}$ It involved hydrazones as electrophilic substrates and provided up to $92 \%$ ee values when using $10 \mathrm{~mol} \%$ of a BINOL-derived ligand. Since then, other types of chiral ligands, including bisoxazolines, amines, amino alcohols, and other BINOL-derivatives etc., have been successfully investigated in these reactions. For example, a chiral Pybox ligand was employed by the Yoda group in 2013/2014 to develop the first highly enantioselective indium-catalyzed allylation of isatins $\mathbf{1}$ with functionalized $\beta$-carbonyl allylstannanes $2 .{ }^{12}$ As illustrated in Scheme 1, this highly efficient process involved a chiral indium catalyst at $10 \mathrm{~mol} \%$ of catalyst loading, which was in situ generated from $\operatorname{In}(\mathrm{OTf})_{3}$ and chiral Pybox ligand 3 , in acetonitrile as solvent. It afforded a range of chiral amide allylated acyclic 2-oxindoles 4 in generally both excellent yields (88->99\%) and enantioselectivities (90-99\% ee). Indeed, various $\mathrm{N}$-alkyl- and $\mathrm{N}$-phenylisatins as well as $\mathrm{N}$ unsubstituted isatins $\left(R^{1}=H\right)$ reacted smoothly with a series of $N$-alkyl and $N$-aryl $\beta$-amido allylstannanes. Only in the case of a $N, N$-disubstituted $\beta$-amido derivative $\left(\mathrm{R}^{2}=\right.$ $\mathrm{NMePh}$ ) lacking the amide $\mathrm{NH}$ proton was a much lower yield (37\%) and enantioselectivity (66\% ee) obtained. This result suggested that the $\mathrm{NH}$-containing amide functionality could play an important role in enhancing enantioselectivity through specific binding interactions of the stannylated reagent with chiral catalyst-substrate association. The thus formed allylated products $\mathbf{4}$ were further converted with complete retention of enantioselectivity by treatment with $p$ - $\mathrm{TsOH}$ in dichloromethane at room temperature into the corresponding expected almost enantiopure spiro- fused 2-oxindole $/ \alpha$-methylene- $\gamma$-butyrolactones $\mathbf{5}$, which were synthesized for the first time and constitute potent biologically active products. ${ }^{13}$

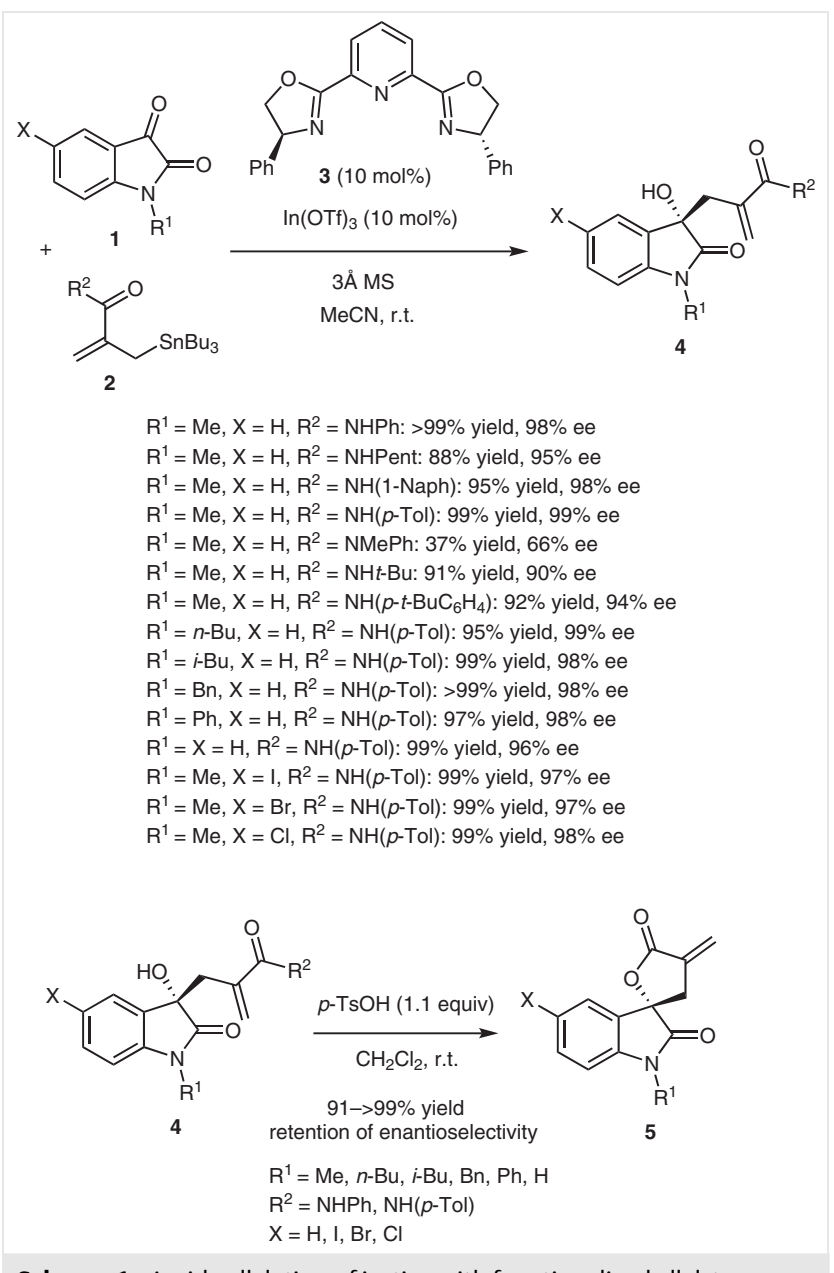

Scheme 1 Amide allylation of isatins with functionalized allylstannanes

In 2014, the Yoda group applied these conditions to challenging acyclic $\alpha$-keto esters $\mathbf{6}$, thus performing the first catalytic enantioselective amide allylation of these substrates (Scheme 2). ${ }^{14}$ Indeed, acyclic $\alpha$-keto esters 6 
reacted with functionalized allylstannanes $\mathbf{2}$ to give the corresponding almost enantiopure homoallylic alcohols $\mathbf{7}$ in good to quantitative yields (72-99\%). The process showed a wide substrate scope for both of the two substrates. Thus, many stannylated reagents $\mathbf{2}$ bearing either aromatic or alkyl groups $\left(\mathrm{R}^{3}\right)$ gave comparable excellent results. The reaction of benzoyl formates $\left(\mathrm{R}^{1}=\mathrm{Ph}\right)$ provided uniformly remarkable yields (96-99\%) and enantioselectivities (96-99\% ee) while that of methyl pyruvate $\left(\mathrm{R}^{1}=\mathrm{Me}\right)$ led to the corresponding product with comparable excellent ee value (99\% ee) albeit combined with a lower yield (72\%). These chiral products were further converted by treatment with $p$-TsOH in DCE at $50{ }^{\circ} \mathrm{C}$ into the corresponding enantiopure $\alpha$-methylene- $\gamma$-butyrolactones $\mathbf{8}$ in high yields (68$99 \%$ ) without noticeable degradation of the enantiopurity.

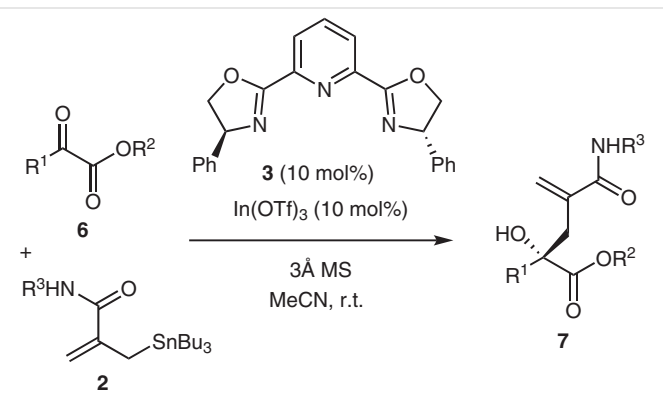

with $\mathrm{R}^{1}=\mathrm{Ph}, \mathrm{R}^{2}=\mathrm{Me}, \mathrm{Bn}, j-\mathrm{Pr}, \mathrm{R}^{3}=p-\mathrm{Tol}, \mathrm{Ph}, p-(t-\mathrm{Bu}) \mathrm{C}_{6} \mathrm{H}_{4}, \mathrm{Ph}$, 1-Naph, $n$-Pent, $t$-Bu, $p$ - $\mathrm{ClC}_{6} \mathrm{H}_{4}, p-\mathrm{MeOC}_{6} \mathrm{H}_{4}: 96-99 \%$ yield, $96-99 \%$ ee with $\mathrm{R}^{1}=\mathrm{R}^{2}=\mathrm{Me}, \mathrm{R}^{3}=p-\mathrm{MeOC}_{6} \mathrm{H}_{4}: 72 \%$ yield, $99 \%$ ee

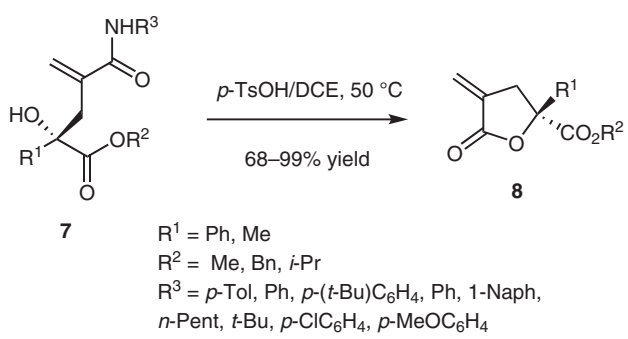

Scheme 2 Amide allylation of acyclic $\alpha$-keto esters with functionalized allylstannanes

The Barbier-type allylation of ketones using allyl halides and indium metal constitutes a direct route to homoallylic alcohols. ${ }^{7}$ Most of the asymmetric versions of this reaction have been developed in organic solvents. In 2017, Nakamura and co-workers disclosed the first enantioselective Barbiertype allylation of ketones performed in water, providing high enantioselectivities of up to $89 \%$ ee. ${ }^{15}$ As shown in Scheme 3, ketones 9 reacted at $0{ }^{\circ} \mathrm{C}$ with allyl bromide 10 in the presence of 2 equivalents of indium and $10 \mathrm{~mol} \%$ of chiral bisimidazoline ligand $\mathbf{1 1}$ to afford the corresponding chiral homoallylic alcohols $\mathbf{1 2}$ in moderate to high enantioselectivities (55-89\% ee) and yields (40-99\%). The catalyst system was compatible with variously substituted ace- tophenones $(\mathrm{R}=\mathrm{Me})$ and trifluoromethyl ketones $\left(\mathrm{R}=\mathrm{CF}_{3}\right)$. The presence of halogen groups in para and meta positions of the phenyl group of the ketone was compatible, leading to good to high ee values (59-89\% ee). That of electrondonating groups $\left(\mathrm{Ar}=m\right.$-Tol, $m$ - $\left.\mathrm{MeOC}_{6} \mathrm{H}_{4}\right)$ also allowed high enantioselectivities (74-84\% ee) to be achieved. The lowest ee value (55\% ee) was obtained in the reaction of the 3-thienyl-substituted ketone $(\mathrm{Ar}=3$-thienyl).

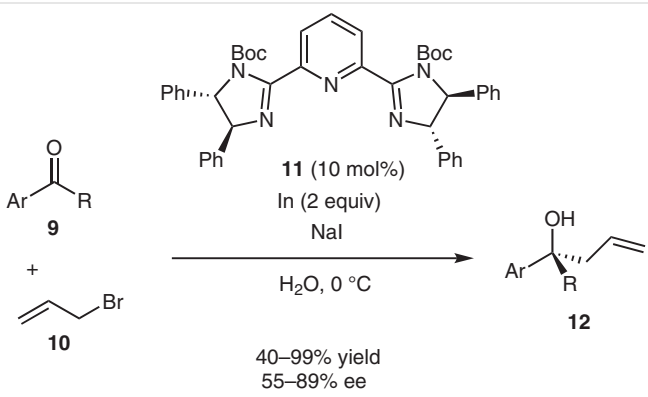

$$
\begin{aligned}
& \mathrm{Ar}=\mathrm{Ph}, m-\mathrm{BrC}_{6} \mathrm{H}_{4}, m-\mathrm{FC}_{6} \mathrm{H}_{4}, m-\mathrm{ClC}_{6} \mathrm{H}_{4}, m-\mathrm{IC}_{6} \mathrm{H}_{4}, o-\mathrm{BrC}_{6} \mathrm{H}_{4}, \\
& p-\mathrm{BrC}_{6} \mathrm{H}_{4}, m-\mathrm{MeOC}_{6} \mathrm{H}_{4}, m \text {-Tol, 3-thienyl, 2-Naph } \\
& \mathrm{R}=\mathrm{Me}, \mathrm{CF}_{3}
\end{aligned}
$$

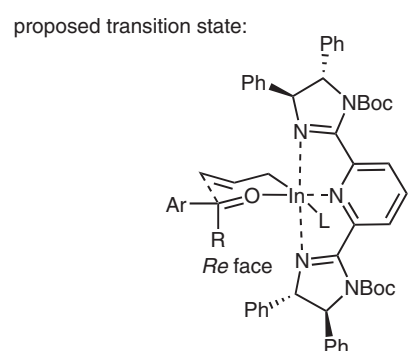

Scheme 3 Barbier-type allylation of acyclic ketones with allyl bromide

While the use of indium(III) complexes as Lewis acids is the most employed, that of indium(I) catalysts remains much less developed. The particularity of these complexes is that they can act as both Lewis acids and Lewis bases because they have both vacant $\mathrm{p}$ orbitals and a lone pair of electrons. This potential ambiphilicity may offer a unique reactivity and selectivity in catalysis. In 2010/2011, the Kobayashi group firstly introduced asymmetric indium(I) catalysis in allylation reactions. ${ }^{16}$ Indeed, they demonstrated the use of indium(I) catalysts for carbon-carbon bond formation between boron-based pronucleophiles and various electrophiles. ${ }^{17}$ For example, a chiral catalyst in situ generated from $5 \mathrm{~mol} \%$ of InI and the same quantity of chiral oxazoline ligand $\mathbf{1 3}$ was found to promote at $0{ }^{\circ} \mathrm{C}$ the asymmetric allylation of hydrazones 14 with allyl pinacol boronate 15. The process performed in a mixture of toluene and methanol as solvent led to the formation of the corresponding chiral hydrazines $\mathbf{1 6}$ in uniformly excellent yields (85->99\%), as presented in Scheme 4. High enantioselectivities (80-96\% ee) were achieved in the reaction of a range of variously substituted aromatic or heteroaromatic hydrazones 


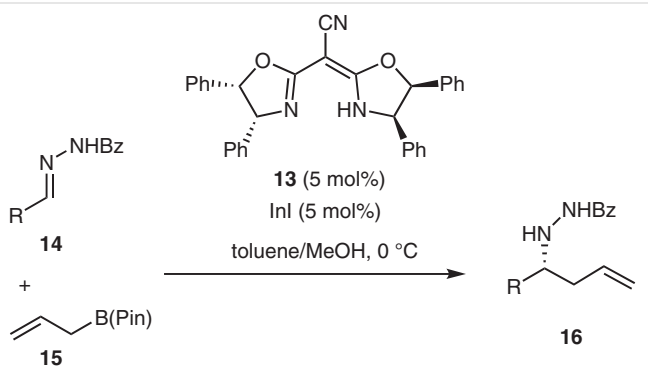

$\mathrm{R}=\mathrm{Ph}, p$-Tol, $p$ - $\mathrm{PhC}_{6} \mathrm{H}_{4}, p-\mathrm{MeOC}_{6} \mathrm{H}_{4}, m-\mathrm{MeOC}_{6} \mathrm{H}_{4}, o-\mathrm{MeOC}_{6} \mathrm{H}_{4}$, $p$ - $\mathrm{HOC}_{6} \mathrm{H}_{4}, p-\mathrm{Me}_{2} \mathrm{NC}_{6} \mathrm{H}_{4}, p-\mathrm{O}_{2} \mathrm{NC}_{6} \mathrm{H}_{4}, 2$-thienyl, 3-furyl, 2-Naph, pyridyl: $85->99 \%$ yield, $80-96 \%$ ee $\mathrm{R}=\mathrm{Cy}: 87 \%$ yield, $30 \%$ ee

Scheme 4 Allylation of hydrazones with allyl pinacol boronate

while an aliphatic hydrazone $(\mathrm{R}=\mathrm{Cy})$ reacted with a much lower enantioselectivity ( $30 \%$ ee).

The Kobayashi group also studied the asymmetric crotylation ( $\mathrm{X}=\mathrm{Me}$ ) of (hetero)aromatic hydrazones 14 with $\alpha$ methylallyl pinacol boronate 17a under the same reaction conditions. ${ }^{17}$ As illustrated in Scheme 5, only the $\alpha$-adducts 18a $(\mathrm{X}=\mathrm{Me})$ were generated as major anti-diastereomers with good to high diastereoselectivities (75-90\% de), high yields (81-98\%) and enantioselectivities (84-94\% ee). Furthermore, comparable results (71-89\% yield, $94-98 \%$ de, $81-86 \%$ ee) were achieved in the asymmetric $\alpha$-chloroallylation $(\mathrm{X}=\mathrm{Cl})$ of aromatic hydrazones 14 with $\alpha$-chloroallyl pinacol boronate $\mathbf{1 7 b}$, affording the corresponding chiral $\alpha$-anti-chlorinated products $\mathbf{1 8 b}(\mathrm{X}=\mathrm{Cl})$.

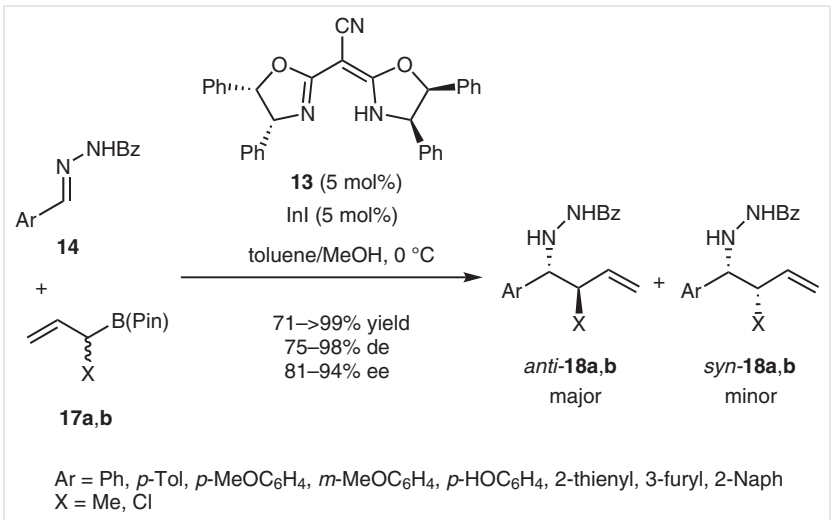

Scheme 5 Crotylation and $\alpha$-chloroallylation of hydrazones with crotyl and $\alpha$-chloroallyl pinacol boronates

In addition, the Kobayashi group selected another indium(I)-based catalyst to promote the asymmetric allylation of $\mathrm{N}, \mathrm{O}$-aminals 19 with allyl pinacol boronate $15 .{ }^{17}$ The indium(I)-based catalyst was generated from $6.5 \mathrm{~mol} \%$ of chiral phosphoramide $\mathbf{2 0}$ and $5 \mathrm{~mol} \%$ of $\mathrm{InCl}$ in a mixture of toluene and cyclopentyl methyl ether (CPME) as solvent. A range of (hetero)aromatic and aliphatic $\mathrm{N}, \mathrm{O}$-aminals 19 were compatible with this catalyst system, providing the corresponding chiral homoallylic amines 21 in excellent yields (88-99\%) and good to high enantioselectivities (72$96 \%$ ee), as shown in Scheme 6.

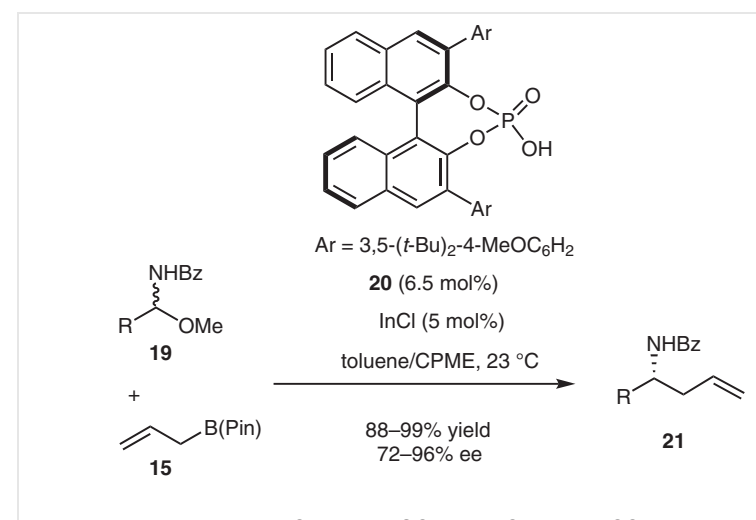

$\mathrm{R}=\mathrm{Ph}, p$-Tol, $p$ - $\mathrm{FC}_{6} \mathrm{H}_{4}, p-\mathrm{MeOC}_{6} \mathrm{H}_{4}, o-\mathrm{FC}_{6} \mathrm{H}_{4}, m-\mathrm{F}_{3} \mathrm{CC}_{6} \mathrm{H}_{4}, m$-Tol, 2-thienyl, 3-furyl, 2-Naph, $m$-Tol, Cy, $n$-Hept

Scheme 6 Allylation of $\mathrm{N}, \mathrm{O}$-aminals with allyl pinacol boronate

3-Aminooxindoles bearing a tetrasubstituted carbon stereocenter at the 3-position are widely found in the core skeletons of many bioactive (natural) products and, consequently, their synthesis is widely developed. On the other hand, the asymmetric allylation of isatimines remained a challenge until 2016 when Cai and Chen reported a highly enantioselective allylation of $\mathrm{N}$-aryl-isatimines $\mathbf{2 2}$ with allyltributyltin (23) promoted by $2.5 \mathrm{~mol} \%$ of a chiral indium catalyst in situ generated from $\operatorname{In}(\mathrm{OTf})_{3}$ and chiral imidazolylpyridine ligand 24 (Scheme 7). ${ }^{18}$ The transformation was carried out at room temperature in methanol as solvent, delivering the corresponding chiral 3-allyl-3-aminooxindoles 25 in uniformly high yields (81-91\%) combined with moderate to excellent enantioselectivities (43-97\% ee). A range of variously substituted $N$-aryl-isatimines 22 were compatible, but it was found that $N^{1}$-unsubstituted isatins $\left(\mathrm{R}^{1}=\mathrm{H}\right)$ allowed higher ee values to be obtained (60$97 \%$ ee) in comparison with $N^{1}$-phenyl- or $N^{1}$-alkyl-substituted isatins (43-74\% ee). To explain the stereoselectivity of the process, the authors proposed the formation of an allylcoordinated transition state with the allyl group positioned in close proximity to the ketimine group (Scheme 7). In this context, the enantioselective allylation occurred through the $R e$-face of the ketimine, resulting in the formation of the (S)-configured amine.

In 2005, Cook and co-workers reported the first example of enantioselective indium-mediated allylation of hydrazones with allyl iodide using $10 \mathrm{~mol} \%$ of $(R)$-3,3'-bis(trifluoromethyl)-BINOL ligand to afford the corresponding chiral homoallylic amines with enantioselectivities of up to $92 \%$ ee. ${ }^{11}$ In 2016, they found that using a new type of chiral ligands in these reactions, such as chiral perfluoroalkylsulfonate BINOLs, improved the enantioselectivity of these reactions to $99 \%$ ee (Scheme 8$).{ }^{19}$ Indeed, when the allylation 

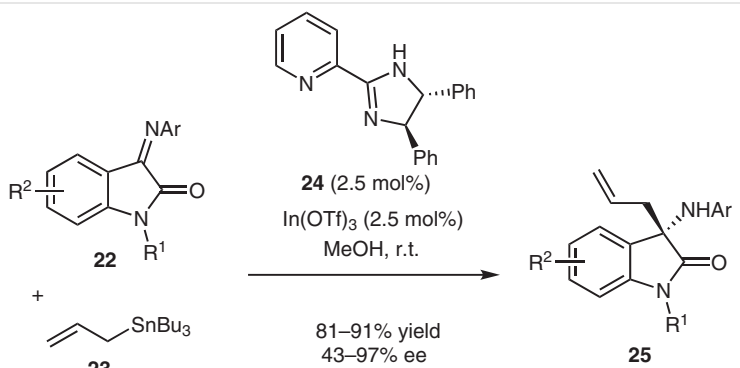

23

$\mathrm{Ar}=p-\mathrm{MeOC}_{6} \mathrm{H}_{4}, \mathrm{R}^{1}=\mathrm{R}^{2}=\mathrm{H}: 91 \%$ yield, $94 \%$ ee

$\mathrm{Ar}=\mathrm{Ph}, \mathrm{R}^{1}=\mathrm{R}^{2}=\mathrm{H}: 87 \%$ yield, $84 \%$ ee

$\mathrm{Ar}=p$-Tol, $\mathrm{R}^{1}=\mathrm{R}^{2}=\mathrm{H}: 89 \%$ yield, $72 \%$ ee

$\mathrm{Ar}=p-\mathrm{ClC}_{6} \mathrm{H}_{4}, \mathrm{R}^{1}=\mathrm{R}^{2}=\mathrm{H}: 87 \%$ yield, $94 \%$ ee

$\mathrm{Ar}=p-\mathrm{BrC}_{6} \mathrm{H}_{4}, \mathrm{R}^{1}=\mathrm{R}^{2}=\mathrm{H}: 90 \%$ yield, $91 \%$ ee

$\mathrm{Ar}=m-\mathrm{Tol}, \mathrm{R}^{1}=\mathrm{R}^{2}=\mathrm{H}: 88 \%$ yield, $97 \%$ ee

$\mathrm{Ar}=0$-Tol, $\mathrm{R}^{1}=\mathrm{R}^{2}=\mathrm{H}: 83 \%$ yield, $83 \%$ ee

$\mathrm{Ar}=p-\mathrm{MeOC}_{6} \mathrm{H}_{4}, \mathrm{R}^{1}=\mathrm{Me}, \mathrm{R}^{2}=\mathrm{H}: 85 \%$ yield, $43 \%$ ee

$\mathrm{Ar}=p-\mathrm{MeOC}_{6} \mathrm{H}_{4}, \mathrm{R}^{1}=\mathrm{Ph}, \mathrm{R}^{2}=\mathrm{H}: 84 \%$ yield, $63 \%$ ee

$\mathrm{Ar}=p-\mathrm{MeOC}_{6} \mathrm{H}_{4}, \mathrm{R}^{1}=\mathrm{Bn}, \mathrm{R}^{2}=\mathrm{H}: 81 \%$ yield, $74 \%$ ee

$\mathrm{Ar}=p-\mathrm{MeOC}_{6} \mathrm{H}_{4}, \mathrm{R}^{1}=\mathrm{H}, \mathrm{R}^{2}=5-\mathrm{Me}: 88 \%$ yield, $60 \%$ ee

$\mathrm{Ar}=p-\mathrm{MeOC}_{6} \mathrm{H}_{4}, \mathrm{R}^{1}=\mathrm{H}, \mathrm{R}^{2}=5-\mathrm{OMe}: 86 \%$ yield, $71 \%$ ee

$\mathrm{Ar}=p-\mathrm{MeOC}_{6} \mathrm{H}_{4}, \mathrm{R}^{1}=\mathrm{H}, \mathrm{R}^{2}=5-\mathrm{Cl}: 83 \%$ yield, $63 \%$ ee

$\mathrm{Ar}=p-\mathrm{MeOC}_{6} \mathrm{H}_{4}, \mathrm{R}^{1}=\mathrm{H}, \mathrm{R}^{2}=6-\mathrm{Cl}: 91 \%$ yield, $94 \%$ ee

$\mathrm{Ar}=p-\mathrm{MeOC}_{6} \mathrm{H}_{4}, \mathrm{R}^{1}=\mathrm{H}, \mathrm{R}^{2}=7-\mathrm{F}: 87 \%$ yield, $96 \%$ ee

proposed transition state:

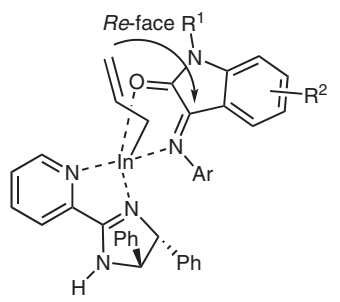

Scheme 7 Allylation of isatimines with allyltributyltin

of a series of (hetero)aromatic and aliphatic hydrazones $\mathbf{2 6}$ with allyl iodide $\mathbf{2 7}(\mathrm{X}=\mathrm{I})$ or bromide $\mathbf{1 0}(\mathrm{X}=\mathrm{Br})$ was promoted by a combination of 2 equivalents of indium with 10 mol\% of BINOL-derived ligand $\mathbf{2 8}$ in THF, it resulted in the formation of the corresponding chiral amines $\mathbf{2 9}$ in high yields (82-98\%) and good to excellent enantioselectivities (70-99\% ee). Especially (hetero)aromatic hydrazones provided uniformly very high ee values (87-99\% ee) while a lower enantioselectivity ( $70 \%$ ee) was obtained in the reaction of an aliphatic hydrazine $\left(\mathrm{R}=\mathrm{BnCH}_{2}\right)$. Interestingly, the BINOL-derived catalyst could be easily recovered by chromatography on silica gel and recycled without loss of activity and enantioselectivity.

In 2017, the Yoda group described the enantioselective amide allylation of $\alpha$-iminoamides $\mathbf{3 0}$ with $N$-substituted $\beta$ amido-allylstannanes $2 .{ }^{20}$ The reaction employed $20 \mathrm{~mol} \%$ of $\mathrm{InCl}_{3}$ as precatalyst and $25 \mathrm{~mol} \%$ of chiral BINOL derivative 31 as ligand in the presence of $10 \mathrm{~mol} \%$ of $\mathrm{ZnCl}_{2}$ as an additive in acetonitrile as solvent. It afforded, at $0{ }^{\circ} \mathrm{C}$, a series of chiral homoallylic amines $\mathbf{3 2}$ in uniformly excellent

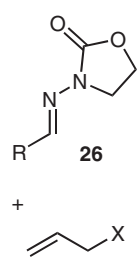

10,27

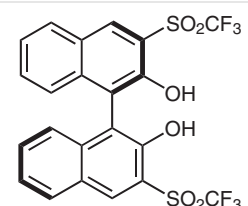

$28(10 \mathrm{~mol} \%)$

In (2 equiv)

$4 \AA ̊ \mathrm{MS}$

$82-98 \%$ yield

$70-99 \%$ ee
THF, $0{ }^{\circ} \mathrm{C}$ to r.t.

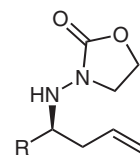

29
$\mathrm{R}=\mathrm{Ph}, p-\mathrm{Tol}, p-\mathrm{MeOC}_{6} \mathrm{H}_{4}, p-\mathrm{ClC}_{6} \mathrm{H}_{4}, o-\mathrm{Tol}, o-\mathrm{ClC}_{6} \mathrm{H}_{4}, o-\mathrm{BrC}_{6} \mathrm{H}_{4}$, 2-Naph, 2-furyl, $\mathrm{BnCH}_{2},(E)-\mathrm{PhCH}=\mathrm{CH}$

$\mathrm{X}=\mathrm{I}, \mathrm{Br}$

Scheme 8 Allylation of hydrazones with allyl iodide and bromide

yields (92-99\%). In the reaction of phenyl $\alpha$-iminoamides $(\mathrm{Ar}=\mathrm{Ph})$ eventually bearing electron-donating or electronwithdrawing groups on the phenyl ring, uniformly high enantioselectivities (82-96\% ee) were achieved while a lower ee value ( $57 \%$ ee) was obtained when a naphthyl-substituted substrate $(\mathrm{Ar}=1-\mathrm{Naph})$ was employed. To demonstrate the utility of this novel methodology, the thus formed chiral amines were converted by treatment with $\mathrm{Boc}_{2} \mathrm{O}$ under basic conditions into the corresponding biologically interesting $\alpha$-methylene- $\gamma$-butyrolactams 33 with high yields (90$98 \%$ ) and retention of enantioselectivity (Scheme 9 ).

\subsection{Propargylations and Allenylations}

Chiral homopropargylic alcohols constitute key intermediates in the synthesis of many complex molecules, including biologically active products. Among metals employed to promote propargylation reactions of carbonyl compounds and derivatives, indium has attracted a special attention from chemists, due to its associated mild reaction conditions, as well as its wide functional group compatibility. The first indium-mediated asymmetric propargylation of aldehydes was pioneered by Loh and co-workers, in $2003 .{ }^{21}$ It involved a stoichiometric amount of cinchonidine as chiral ligand, providing enantioselectivities of up to $84 \%$ ee. Since then, several other types of chiral ligands have been investigated in these transformations, but it must be recognized that this field has remained much less developed than that of asymmetric allylations. As a rare example, an asymmetric Barbier-type propargylation of aldehydes 34 with propargyl bromide (35) was developed by Singaram and co-workers, in 2012. ${ }^{22}$ The process was mediated by 2 equivalents of indium and the same quantity of chiral 1,2amino alcohol 36 as ligand in THF, leading to the corresponding chiral homopropargylic alcohols $\mathbf{3 7}$ in moderate to high yields (53-90\%) and enantioselectivities (74-95\% ee), as illustrated in Scheme 10. The catalyst system tolerated 

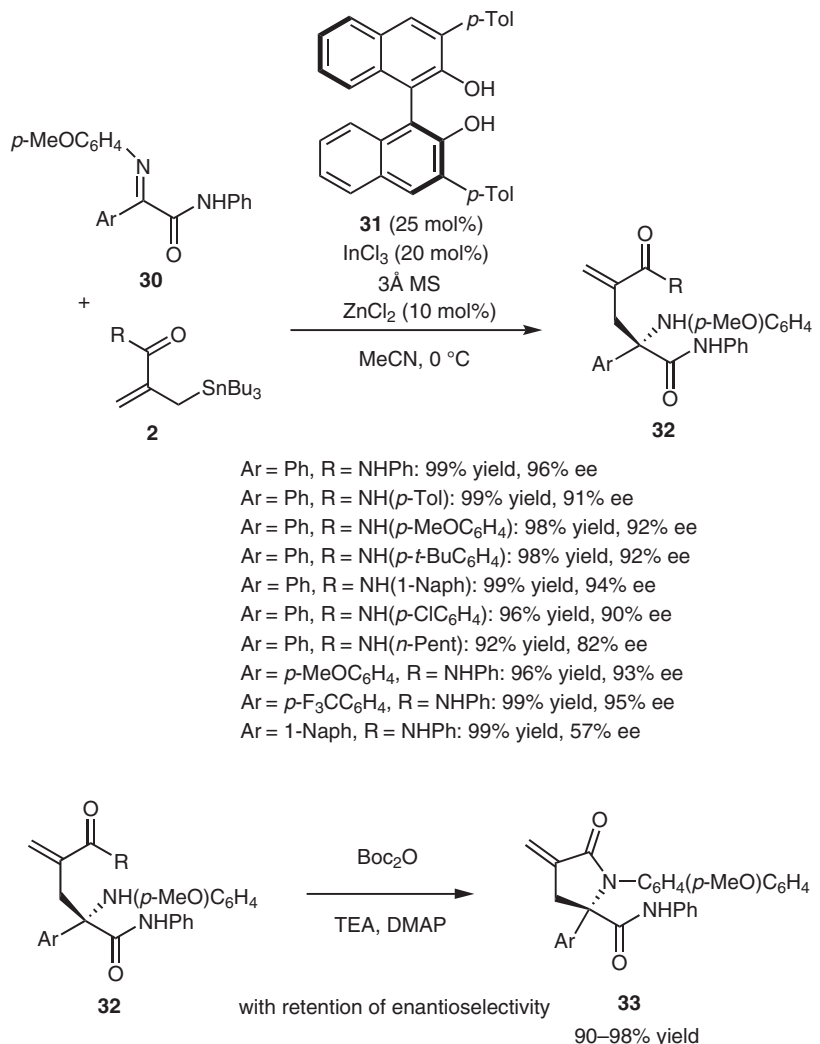

Scheme 9 Amide allylation of $\alpha$-iminoamides with $\beta$-amido allylstannanes

(hetero)aromatic as well as aliphatic aldehydes. However, this methodology was not applicable to the propargylation of ketones. Moreover, a significant drawback of this methodology was related to the requirement for a superstoichiometric amount of chiral ligand.

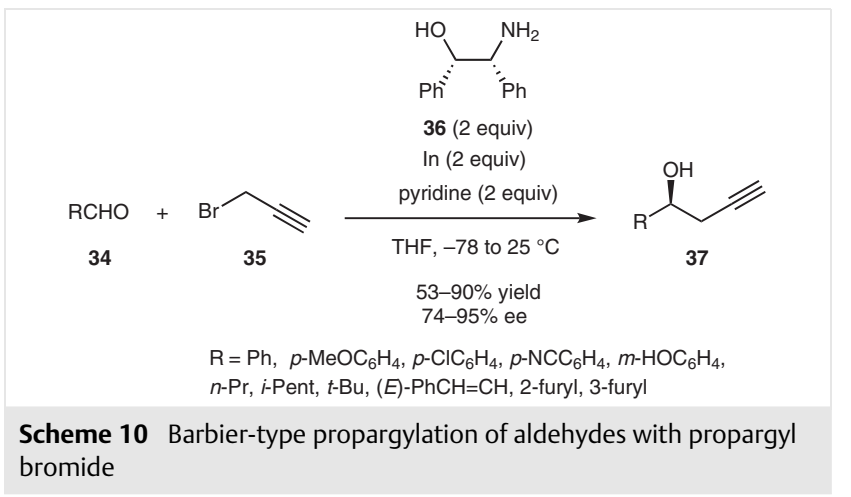

a-Alkynyl amides represent useful building blocks for the synthesis of many heterocyclic systems. Their most direct and economic synthesis is based on amido-functionalized propargylation of aldehydes. Surprisingly, it is only in 2019 that the first example of this methodology was described by the Yoda group. ${ }^{23}$ It involved the amide propar-

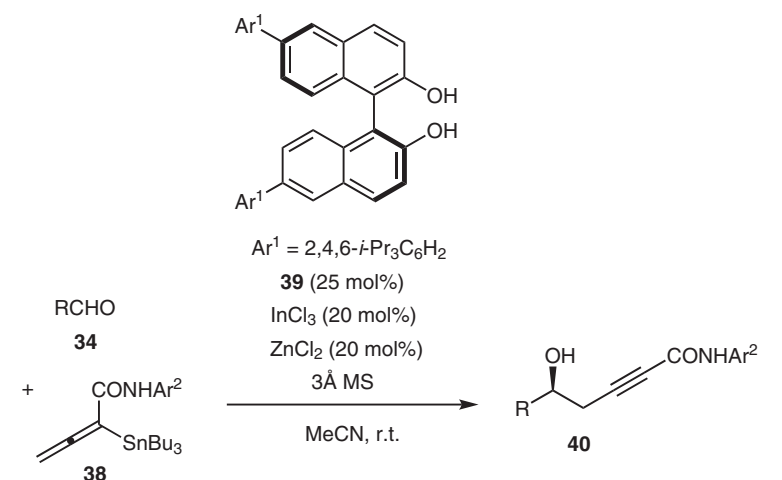

$\mathrm{R}=n-\mathrm{Non}, \mathrm{Ar}^{2}=\mathrm{Ph}: 66 \%$ yield, $60 \%$ ee

$\mathrm{R}=t-\mathrm{Bu}, \mathrm{Ar}^{2}=\mathrm{Ph}: 74 \%$ yield, $66 \%$ ee

$\mathrm{R}=m-\left(\mathrm{Ph}_{2} \mathrm{MeSi}\right) \mathrm{C}_{6} \mathrm{H}_{4}, \mathrm{Ar}^{2}=\mathrm{Ph}: 80 \%$ yield, $82 \%$ ee

$\mathrm{R}=p-\mathrm{Tol}, \mathrm{Ar}^{2}=\mathrm{Ph}: 70 \%$ yield, $74 \%$ ee

$\mathrm{R}=p-\mathrm{MeOC}_{6} \mathrm{H}_{4}, \mathrm{Ar}^{2}=\mathrm{Ph}: 75 \%$ yield, $80 \%$ ee

$\mathrm{R}=p-\mathrm{ClC}_{6} \mathrm{H}_{4}, \mathrm{Ar}^{2}=\mathrm{Ph}: 72 \%$ yield, $84 \%$ ee

$\mathrm{R}=p-\left(\mathrm{Ph}_{2} \mathrm{MeSi}\right) \mathrm{C}_{6} \mathrm{H}_{4}, \mathrm{Ar}^{2}=\mathrm{Ph}: 80 \%$ yield, $84 \%$ ee

$\mathrm{R}=0$-Tol, $\mathrm{Ar}^{2}=\mathrm{Ph}: 78 \%$ yield, $80 \%$ ee

$\mathrm{R}=0-\mathrm{MeOC}_{6} \mathrm{H}_{4}, \mathrm{Ar}^{2}=\mathrm{Ph}: 77 \%$ yield, $80 \%$ ee

$\mathrm{R}=0-\mathrm{ClC}_{6} \mathrm{H}_{4}, \mathrm{Ar}^{2}=\mathrm{Ph}: 77 \%$ yield, $72 \%$ ee

$\mathrm{R}=0-\mathrm{TBSC}_{6} \mathrm{H}_{4}, \mathrm{Ar}^{2}=\mathrm{Ph}: 91 \%$ yield, $94 \%$ ee

$\mathrm{R}=0-\mathrm{TIPSC}_{6} \mathrm{H}_{4}, \mathrm{Ar}^{2}=\mathrm{Ph}: 91 \%$ yield, $92 \%$ ee

$\mathrm{R}=o-\left(\mathrm{Ph}_{2} \mathrm{MeSi}\right) \mathrm{C}_{6} \mathrm{H}_{4}, \mathrm{Ar}^{2}=\mathrm{Ph}: 89 \%$ yield, $96 \%$ ee

$\mathrm{R}=o-\left(\mathrm{Ph}_{2} \mathrm{MeSi}\right) \mathrm{C}_{6} \mathrm{H}_{4}, \mathrm{Ar}^{2}=p-\mathrm{ClC}_{6} \mathrm{H}_{4}: 87 \%$ yield, $90 \%$ ee

$\mathrm{R}=o-\left(\mathrm{Ph}_{2} \mathrm{MeSi}\right) \mathrm{C}_{6} \mathrm{H}_{4}, \mathrm{Ar}^{2}=p-\mathrm{MeOC}_{6} \mathrm{H}_{4}: 89 \%$ yield, $92 \%$ ee

$\mathrm{R}=o-\left(\mathrm{Ph}_{2} \mathrm{MeSi}\right) \mathrm{C}_{6} \mathrm{H}_{4}, \mathrm{Ar}^{2}=p-$ Tol: $87 \%$ yield, $94 \%$ ee

Scheme 11 Propargylation of aldehydes with stannylated allenyl amides

gylation of aromatic and aliphatic aldehydes $\mathbf{3 4}$ with newly prepared stannyl allenyl amides $\mathbf{3 8}$ achieved in the presence of only catalytic amounts of $\mathrm{InCl}_{3}(20 \mathrm{~mol} \%$ ) as precatalyst, chiral BINOL-derived ligand 39 (25 mol\%), and $\mathrm{ZnCl}_{2}$ (20 mol\%) as an additive. As depicted in Scheme 11, a range of chiral amide-functionalized homopropargylic alcohols $\mathbf{4 0}$ were synthesized at room temperature in acetonitrile as solvent with good to high yields (66-91\%) and moderate to excellent enantioselectivities (60-96\% ee). Generally, the reaction of aromatic aldehydes provided higher enantioselectivities (72-96\% ee) than that of aliphatic aldehydes ( $\mathrm{R}=n-$ Non, $t-\mathrm{Bu}, 60-66 \%$ ee).
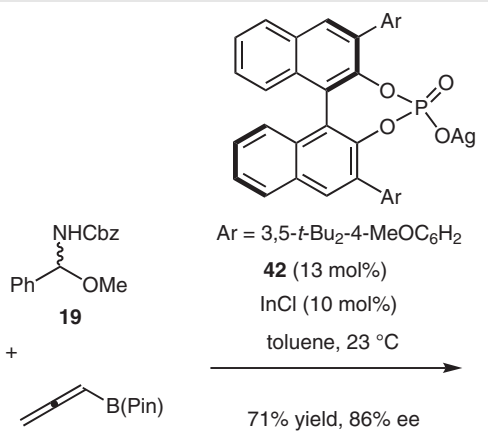

$$
\mathrm{Ar}=3,5-t-\mathrm{Bu}_{2}-4-\mathrm{MeOC}_{6} \mathrm{H}_{2}
$$

$$
42(13 \mathrm{~mol} \%)
$$

$\operatorname{lnCl}(10 \mathrm{~mol} \%)$
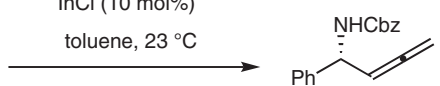

$71 \%$ yield, $86 \%$ ee

43

41

Scheme 12 Allenylation of an N,O-aminal with allenyl pinacol boronate 
In 2012, the Kobayashi group reported the asymmetric allenylation of $\mathrm{N}, \mathrm{O}$-aminal 19 with allenyl pinacol boronate 41 promoted by a catalyst system composed of $10 \mathrm{~mol} \%$ of InCl and $13 \mathrm{~mol} \%$ of chiral silver BINOL-phosphate $42 .{ }^{17}$ Performed in toluene at $23^{\circ} \mathrm{C}$, the reaction afforded regioselectively chiral homoallenyl carbamate $\mathbf{4 3}$ as major product in $71 \%$ yield and $86 \%$ ee (Scheme 12 ).

\section{Cycloadditions}

\subsection{Hetero-Diels-Alder Cycloadditions}

In 1999, Frost and co-workers disclosed the first use of In $(\mathrm{OTf})_{3}$ to promote hetero-Diels-Alder reactions. ${ }^{24}$ Indeed, in the presence of only $0.5 \mathrm{~mol} \%$ of this catalyst the iminoDiels-Alder reaction between imines and dienes provided the cycloadducts in excellent yields. Then in 2012, Luo and co-workers disclosed the first regio- and enantioselective hetero-Diels-Alder cycloaddition of $\beta, \gamma$-unsaturated $\alpha$-keto esters $\mathbf{4 4}$ with cyclopentadiene and monosubstituted cyclopentadienes $\mathbf{4 5}$ as well as disubstituted cyclopentadienes 46 catalyzed by a unique binary-acid catalyst system composed of $\mathrm{InBr}_{3}$ and chiral phosphoric acid 47.25 This dual catalyst was extremely active since only $1 \mathrm{~mol} \%$ and $2 \mathrm{~mol} \%$ of catalyst loading in $\mathrm{InBr}_{3}$ and chiral phosphoric acid, respectively, were sufficient to promote the transformation. As shown in Scheme 13, unsubstituted and monosubstituted cyclopentadienes 45 reacted with aryl $\beta, \gamma$-unsaturated $\alpha$-keto esters $\mathbf{4 4}$ to give a mixture of expected enantiopure hetero-Diels-Alder products $\mathbf{4 8}$ as major products along with carbon-Diels-Alder cycloadducts $\mathbf{4 9}$ as minor products in 78:22 to $87: 13$ ratios. Both the yields of the reaction (88-99\%) and enantiopurities of the major products (98$>99 \%$ ee) were excellent. In the case of disubstituted cyclopentadienes 46, the reactions with both aryl and alkyl $\beta, \gamma-$ unsaturated methyl $\alpha$-keto esters $\mathbf{4 4}$ proceeded exclusively to give the corresponding chiral hetero-Diels-Alder cycloadducts $\mathbf{5 0}$ as single regioisomers. Moreover, these products were obtained almost enantiopure (94->99\% ee) in high to quantitative yields (85-99\%).

The asymmetric hetero-Diels-Alder cycloaddition of Danishefsky's dienes with aldehydes is also very attractive since the formed enantioenriched oxygen-containing sixmembered heterocycles generated in this reaction are versatile building blocks for the synthesis of numerous biologically active compounds. In this context, in 2013 Loh and Zhao developed the enantioselective indium-catalyzed hetero-Diels-Alder of glyoxylates $\mathbf{6}\left(\mathrm{R}^{2}=\mathrm{H}\right)$ with Danishefsky's diene $51\left(R^{3}=H\right)$ (Scheme 14). ${ }^{26}$ The reaction was catalyzed at room temperature in dichloromethane as solvent by a combination of $10 \mathrm{~mol} \%$ of $\mathrm{InI}_{3}$ and $12 \mathrm{~mol} \%$ of chiral Pybox

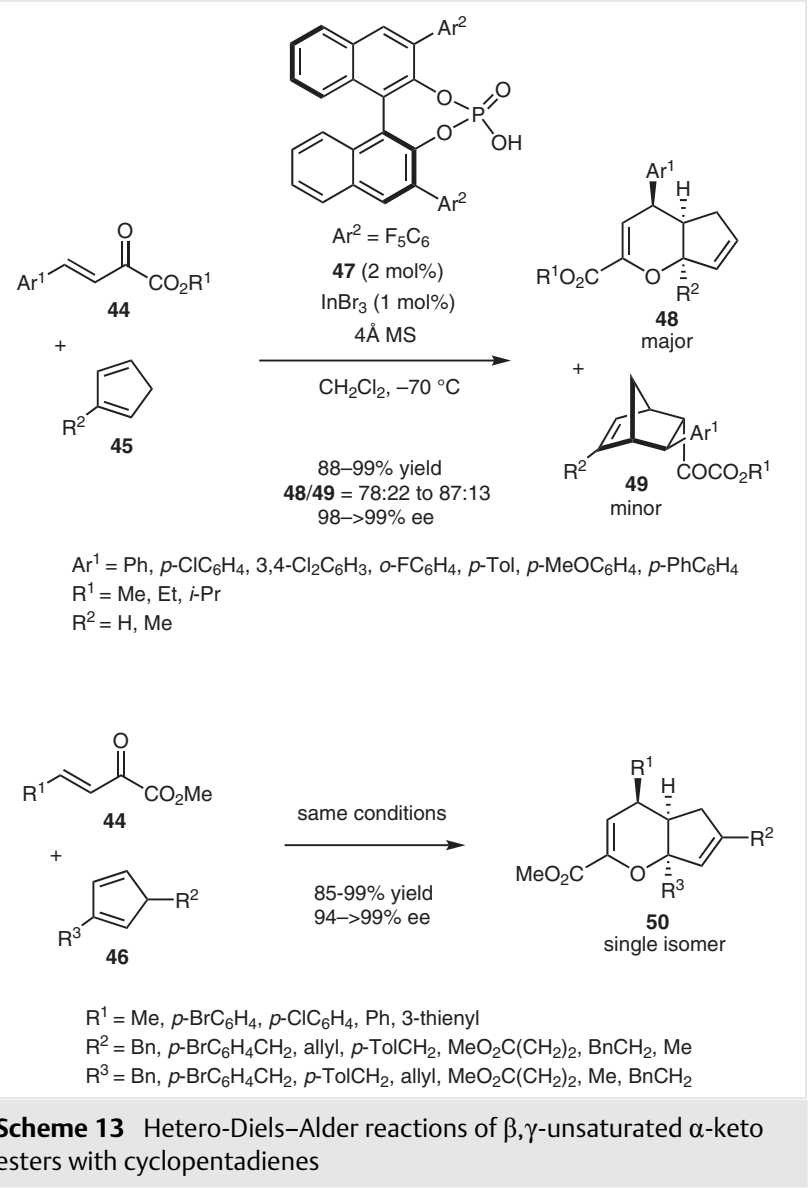

ligand 52 and gave the corresponding chiral cycloadducts 53 in good yields (59-80\%) and moderate to high enantioselectivities (50-93\% ee). The best enantioselectivities (9293\% ee) were achieved in the reaction of tert-butyl glyoxylate $\left(\mathrm{R}^{1}=t-\mathrm{Bu}\right)$ while much lower ee values were obtained with less sterically hindered esters $\left(\mathrm{R}^{1}=i\right.$-Pr: $70 \%$ ee, $\mathrm{R}^{1}=$ Me, Et: $50-63 \%$ ee). The scope of the process could be extended to more challenging $\alpha$-keto esters $6\left(R^{2} \neq H\right)$ which reacted with Danishefsky's dienes $\mathbf{5 1}$ to afford the corresponding chiral cycloadducts $\mathbf{5 3}$ in variable yields (10-84\%) and enantioselectivities (30-95\% ee). Again, the steric hindrance of the $\alpha$-keto ester played a key role in both the yield and enantioselectivity of the reaction. For example, they were found much lower (10-48\% yield, $30 \%$ ee) when the substituents at the $\alpha$-position of the carbonyl group were bromomethyl and isopropyl whereas the presence of meth$\mathrm{yl}$ and linear (trimethylsilyl)ethynyl groups allowed much better ee values (87-95\% ee) and yields (52-84\%) to be achieved. 


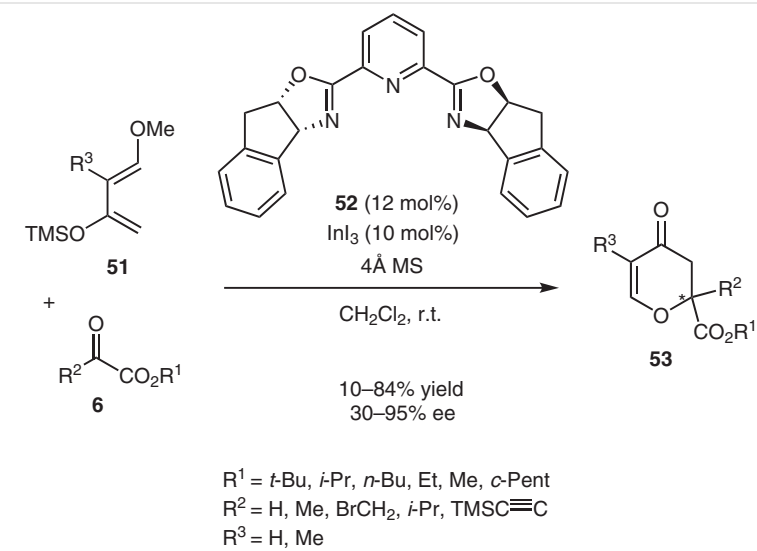

Scheme 14 Hetero-Diels-Alder reaction of $\alpha$-carbonyl esters with Danishefsky's dienes

The related hetero-Diels-Alder cycloaddition of allenes with $\alpha, \beta$-unsaturated conjugated compounds also provides a powerful tool for the rapid construction of six-membered heterocycles. ${ }^{27}$ Surprisingly, even if various organocatalytic asymmetric versions of this methodology have been successfully developed, the first asymmetric metal-catalyzed version was only reported in 2017 by Luo, Lv, and co-workers by involving an indium catalyst. ${ }^{28}$ As illustrated in Scheme 15 , the cycloaddition of $\beta, \gamma$-unsaturated $\alpha$-keto esters 44 with non-activated allenes 54 was promoted at room temperature by a combination of $5 \mathrm{~mol} \%$ of $\mathrm{InBr}_{3}$ and $10 \mathrm{~mol} \%$ of chiral silver phosphate $\mathbf{5 5}$ in chloroform as solvent. The corresponding chiral dihydropyrans $\mathbf{5 6}$ were produced as major $Z$-isomers in moderate to high yields (35$90 \%$ ) and moderate to excellent enantioselectivities (66$99 \%$ ee). The reaction of monosubstituted allenes all provided uniformly excellent ee values (87-99\% ee) while that of

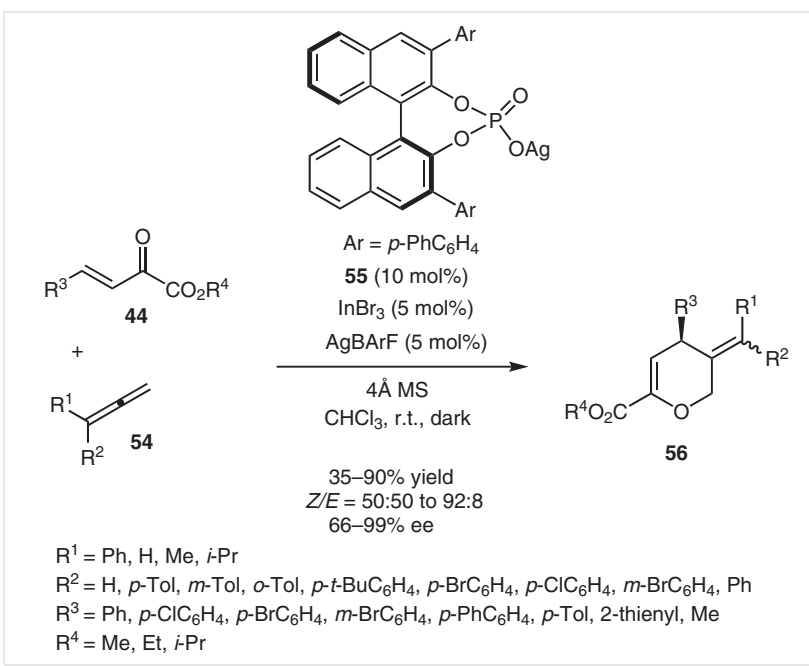

Scheme 15 Hetero-Diels-Alder reaction of $\beta, \gamma$-unsaturated $\alpha$-keto esters with non-activated allenes 1,1-disubstituted allenes generally gave lower enantioselectivities (66-93\% ee).

Chiral 0,0 -acetals are versatile structural motifs in many natural products and bioactive compounds, such as carbohydrates, chromene acetal derivatives, and spiroketal polyketides. In 2018, Luo, Lv, and co-workers disclosed a novel route to these products based on the first catalytic enantioselective hetero-Diels-Alder reaction of $\beta, \gamma$-unsaturated $\alpha$-keto esters $\mathbf{4 4}$ with alkoxyallenes $\mathbf{5 7 . 2 9}$ This process was catalyzed by a combination of $5 \mathrm{~mol} \%$ of $\mathrm{InCl}$ with the same quantity of chiral phosphoric acid 58. Performed at room temperature in ethyl acetate as solvent, it yielded regioselectively the corresponding chiral cyclic 0,0 -acetals $\mathbf{5 9}$ in moderate to quantitative yields (40-99\%) and uniformly excellent enantioselectivities (89-99\% ee), as shown in Scheme 16.

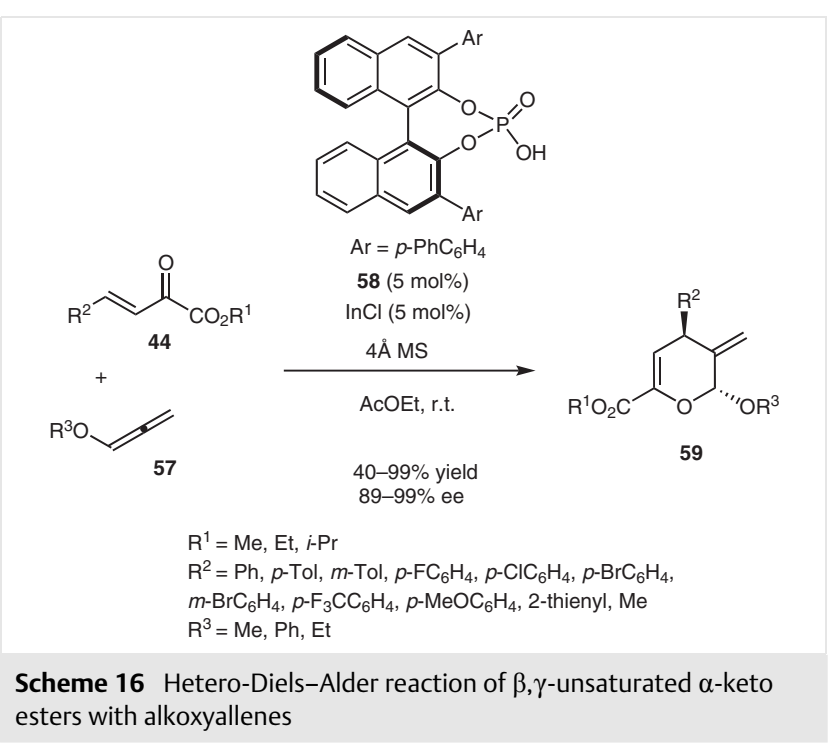

\subsection{1,3-Dipolar Cycloadditions}

The 1,3-dipolar cycloaddition is a powerful reaction between 1,3-dipoles, such as nitrones, and dipolarophiles to produce five-membered-ring systems. ${ }^{30}$ In 2017, Shibasaki, Kumagai, and Zhang reported an enantioselective indiumcatalyzed 1,3-dipolar cycloaddition between nitrones $\mathbf{6 0}$ and $\alpha, \beta$-unsaturated 7-azaindoline amides $\mathbf{6 1}$ (Scheme 17). ${ }^{31}$ The catalyst was in situ generated in THF as solvent from $10 \mathrm{~mol} \%$ of $\operatorname{In}(\mathrm{OTf})_{3}$ and $12 \mathrm{~mol} \%$ of chiral bishydroxamic acid 62. The process was exo-selective and led at room temperature to the corresponding exo-cycloadducts 63 with good to high yields (67-93\%), uniformly high enantioselectivities (79-99\% ee) and moderate to almost complete exo-selectivity (exo/endo $=83: 17$ to $>95: 5$ ). The use of $\alpha, \beta$-unsaturated 7-azaindoline amides as dipolarophiles was crucial to elicit both high reactivity and stereoselectivity. The best diastereo- and enantioselectivities (>90\% de, 
83-99\% ee) were achieved in the reaction of aromatic/aliphatic nitrones $\mathbf{6 0}$ to give products $\mathbf{6 3}$ while slightly lower enantioselectivities (79-90\% ee) combined with moderate to high exo-selectivities (66-86\% de) were obtained in the reaction of aliphatic/aliphatic nitrones $\mathbf{6 0}$ with $\alpha, \beta$-unsaturated 7 -azaindoline amides $\mathbf{6 1}$ to give the corresponding products 64 in high yields (83-91\%) by using a related chiral bishydroxamic acid 65 as ligand (Scheme 17).
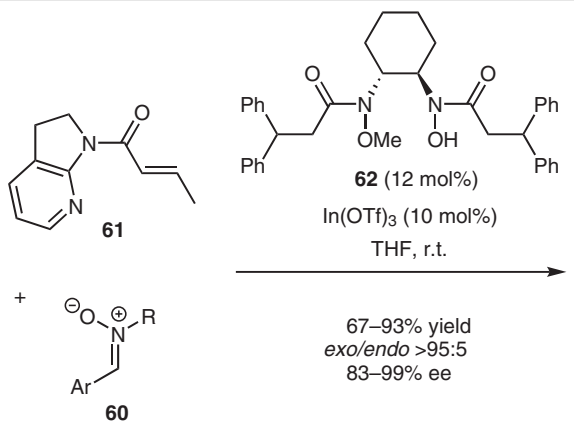

$\mathrm{R}=\mathrm{Bn}, \mathrm{Me}$

$\mathrm{Ar}=\mathrm{Ph}, 2-\mathrm{Naph}, o-\mathrm{Tol}, m$-Tol, $p$-Tol, $p$ - $\mathrm{F}_{3} \mathrm{CC}_{6} \mathrm{H}_{4}, p-\mathrm{FC}_{6} \mathrm{H}_{4}, p-\mathrm{ClC}_{6} \mathrm{H}_{4}, p-\mathrm{BrC}_{6} \mathrm{H}_{4}$ $o$ - $\mathrm{BrC}_{6} \mathrm{H}_{4}, m-\mathrm{NCC}_{6} \mathrm{H}_{4}, p-\mathrm{MeOC}_{6} \mathrm{H}_{4}, o-\mathrm{MeOC}_{6} \mathrm{H}_{4}, 3$-pyridyl, 2-furyl

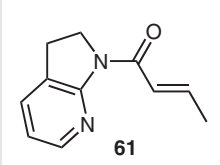

$+\Theta_{O} \stackrel{\oplus}{-}-B n$

60

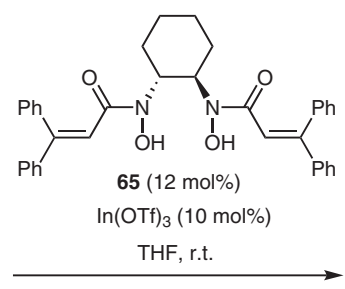

$83-91 \%$ yield xo/endo $=83: 17$ to $93: 7$ $79-90 \%$ ee

$\mathrm{R}=n-\mathrm{Pent}, \mathrm{Cy}, \mathrm{BnCH}_{2}$

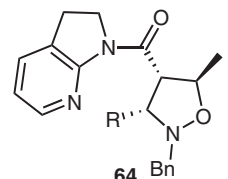

$64 \mathrm{Bn}$
Scheme 17 1,3-Dipolar cycloadditions of nitrones with $\alpha, \beta$-unsaturated 7-azaindoline amides

\section{Miscellaneous Reactions}

The intermolecular carbonyl-ene reaction is one of the most economic methods for the construction of carboncarbon bonds because it involves simple and readily available starting materials. ${ }^{32}$ Many catalytic asymmetric versions of this transformation have been developed so far. Among them, is an enantioselective indium-catalyzed intermolecular carbonyl-ene reaction between trisubstituted alkenes 66 and glyoxylates 67 reported in 2015 by Loh, Xu, and co-workers. ${ }^{33}$ The catalyst employed was in situ generated at room temperature from $10 \mathrm{~mol} \%$ of $\mathrm{InCl}_{3}$ and 12 mol\% of chiral Pybox ligand $\mathbf{5 2}$ in DCE as solvent, allowing a range of chiral homoallylic alcohols $\mathbf{6 8}$ to be simply synthesized with high anti-diastereoselectivities (76-98\% de), homogeneously excellent enantioselectivities (89-99\% ee), and moderate to high yields (55-90\%), as shown in Scheme 18. Various electron-donating and electron-withdrawing groups were tolerated on the phenyl ring of the aryl substituent ( $\mathrm{Ar}$ ) of the trisubstituted alkenes, providing comparable results. It was found that the geometry of the starting alkene was essential for a high reactivity. For example, only trans-alkenes allowed good yields to be achieved.
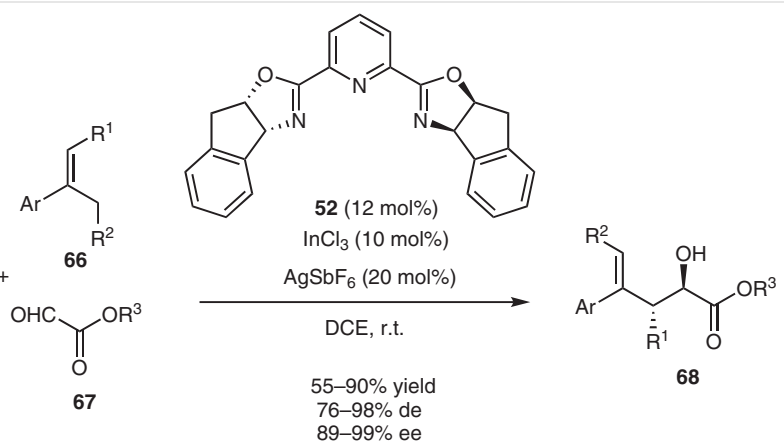

$\mathrm{Ar}=\mathrm{Ph}, m$-Tol, $p$ - Tol, $m-\mathrm{MeOC}_{6} \mathrm{H}_{4}, m-\mathrm{FC}_{6} \mathrm{H}_{4}, p-\mathrm{FC}_{6} \mathrm{H}_{4}, m-\mathrm{ClC}_{6} \mathrm{H}_{4}$, $p-\mathrm{ClC}_{6} \mathrm{H}_{4}, m-\mathrm{BrC}_{6} \mathrm{H}_{4}, o-\mathrm{BrC}_{6} \mathrm{H}_{4}, p-\mathrm{IC}_{6} \mathrm{H}_{4}, 2-\mathrm{Naph}$

$\mathrm{R}^{1}=\mathrm{Me}, n-\mathrm{Pr}$

$\mathrm{R}^{2}=\mathrm{H}, \mathrm{Me}$

$\mathrm{R}^{1}, \mathrm{R}^{2}=\left(\mathrm{CH}_{2}\right)_{2}$

$\mathrm{R}^{3}=\mathrm{Me}, \mathrm{Et}, i-\mathrm{Pr}, n-\mathrm{Bu}$

Scheme 18 Carbonyl-ene reaction of trisubstituted alkenes with glyoxylates

Earlier in 2012, chiral $N, N^{\prime}$-dioxide ligand 69 was employed by Feng and co-workers at only $3.3 \mathrm{~mol} \%$ of catalyst loading in combination with $3 \mathrm{~mol} \%$ of $\operatorname{In}(\mathrm{OTf})_{3}$ to catalyze the enantioselective ring-opening of aromatic meso-epoxides 70 with aromatic amines $\mathbf{7 1} .^{34}$ Performed at $0{ }^{\circ} \mathrm{C}$ in THF as solvent, the reaction led to the corresponding chiral 1,2amino alcohols 72 in both excellent enantioselectivities (91-99\% ee) and yields (89-99\%), as presented in Scheme 19.

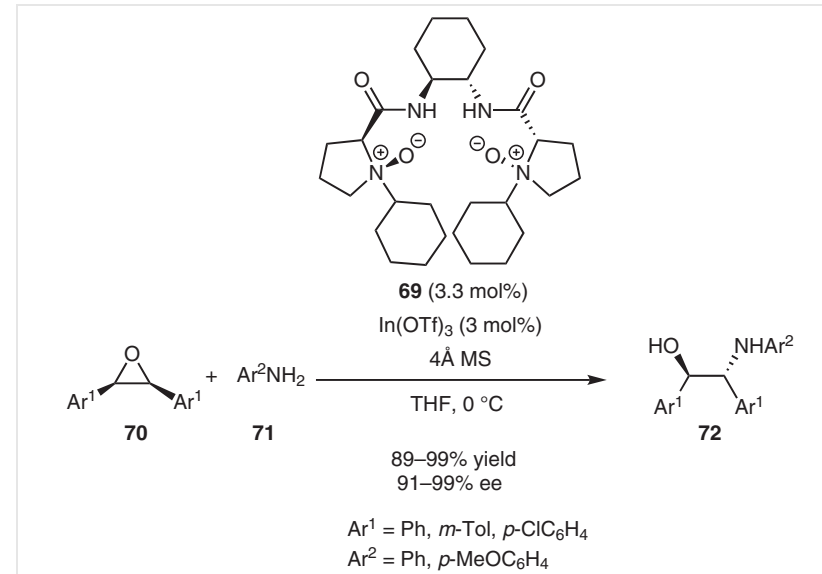

Scheme 19 Ring-opening of aromatic meso-epoxides with aromatic amines 
In another context, in 2012 Cozzi and co-workers developed the enantioselective indium-catalyzed $\alpha$-alkylation of aliphatic aldehydes $\mathbf{7 3}$ with benzylic alcohols $\mathbf{7 4}$ (Scheme 20). ${ }^{35}$ The process was performed at room temperature in hexane as solvent in the presence of $20 \mathrm{~mol} \%$ of In(OTf $)_{3}$ and the same quantity of chiral imidazolidinone 75. Evolving through a $\mathrm{S}_{\mathrm{N}} 1$-type mechanism, the process yielded the corresponding chiral aldehydes $\mathbf{7 6}$ in good to excellent yields (60-90\%), uniformly high enantioselectivities (80$96 \%$ ee) and zero to moderate diastereoselectivities (0-66\% de). The wide scope reflects the compatibility of indium with a range of functional groups exhibited on the benzylic alcohols $\left(\mathrm{R}^{3}\right)$, such as esters, amides, protected amines, and alcohols. Moreover, heteroaromatic substituents were tolerated, although providing moderate diastereoselectivities $\left(\mathrm{R}^{3}=2\right.$ - and 3-thienyl: 4-34\% de). In almost all examples, the presence of a $p-\mathrm{NMe}_{2} \mathrm{C}_{6} \mathrm{H}_{4}$ group $\left(\mathrm{R}^{2}=\mathrm{NMe}_{2}\right)$ on the benzylic alcohol was found essential for obtaining high yields. It must be noted that the formed products constituted useful intermediates for the synthesis of biologically active chiral diarylethane products.

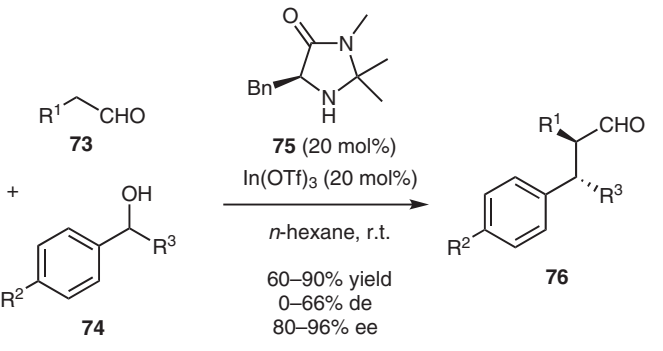

$$
\begin{aligned}
& \mathrm{R}^{1}=\mathrm{Me}, n-\mathrm{Hex} \\
& \mathrm{R}^{2}=\mathrm{NMe}_{2}, \mathrm{OMe} \\
& \mathrm{R}^{3}=p-\mathrm{MeOC}_{6} \mathrm{H}_{4}, \mathrm{Ph}, o-\mathrm{PhC}_{6} \mathrm{H}_{4}, o-\mathrm{MeOC}_{6} \mathrm{H}_{4}, o-\mathrm{BnOC}_{6} \mathrm{H}_{4} \text {, } \\
& \text { 3-thienyl, 2-thienyl, } n \text {-Bu, Et, TBSO }\left(\mathrm{CH}_{2}\right)_{2}, \mathrm{EtO}{ }_{2} \mathrm{C}\left(\mathrm{CH}_{2}\right)_{2} \text {, } \\
& \mathrm{NH}_{2} \mathrm{CO}\left(\mathrm{CH}_{2}\right)_{2}, \mathrm{Boc}(\mathrm{Ph}) \mathrm{N}\left(\mathrm{CH}_{2}\right)_{3}
\end{aligned}
$$

Scheme $20 \alpha$-Alkylation of aldehydes with benzylic alcohols

In 2014, a related catalyst system was also applied by Cozzi and co-workers to the asymmetric $\alpha$-alkylation of $n$-octanal (73a) with allylic and propargylic alcohols. ${ }^{36}$ As depicted in Scheme 21, the use of $20 \mathrm{~mol} \%$ of chiral imidazolidinone 77 combined with the same quantity of $\mathrm{InBr}_{3}$ in dichloromethane at $0{ }^{\circ} \mathrm{C}$ allowed the asymmetric $\alpha$-allylation of $n$-octanal (73a) with aromatic allylic alcohols $\mathbf{7 8}$ to give the corresponding chiral homoallylic aldehydes $\mathbf{7 9}$ as major syn-products with moderate diastereoselectivities (34-50\% de) and good yields (53-71\%) along with uniformly high enantioselectivities (85-91\% ee). Then, the $\alpha$-alkylation of $n$-octanal (73a) with propargylic alcohols $\mathbf{8 0}$ was also investigated. In this case, a related catalyst system composed of $20 \mathrm{~mol} \%$ of chiral imidazolidinone $\mathbf{8 1}$ and $20 \mathrm{~mol} \%$ of $\operatorname{In}(\mathrm{OTf})_{3}$ was found optimal to produce, at $0{ }^{\circ} \mathrm{C}$, the corresponding chiral homopropargylic aldehydes 82. Interestingly, the reaction was performed in water and yielded the products as major anti-diastereomers with moderate dia- stereoselectivities (42-44\% de) albeit combined with almost quantitative yields (94-97\%) and homogeneously excellent ee values (97-98\% ee). In these reactions (Schemes 20 and 21), the role of indium was supposed to assist the formation of the benzylic, allylic, or propargylic carbenium ion from the starting alcohol while the amine organocatalyst formed the corresponding enamine of the starting aldehyde which then attacked this carbenium ion.
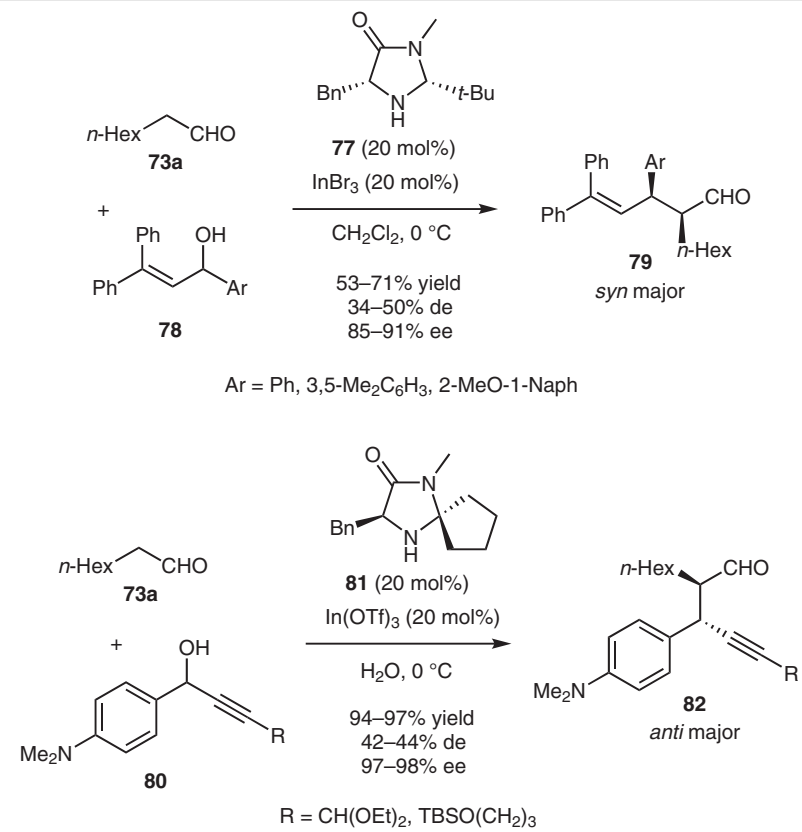

Scheme $21 \alpha$-Alkylations of $n$-octanal with allylic and propargylic alcohols

In the same area, Rueping and co-workers developed the enantioselective $\alpha$-arylation of aldehydes $\mathbf{7 3}$ with quinoline acetals $\mathbf{8 3}$ (Scheme 22). ${ }^{37}$ In this case, the dual catalyst system consisted of $10 \mathrm{~mol} \%$ of $\operatorname{In}(\mathrm{OTf})_{3}$ as Lewis acid and $20 \mathrm{~mol} \%$ of chiral imidazolidinone $\mathbf{7 5}$ as organocatalyst. The process was performed in toluene at $0{ }^{\circ} \mathrm{C}$, resulting in the formation of chiral quinolines 84 in good yields (63-85\%),

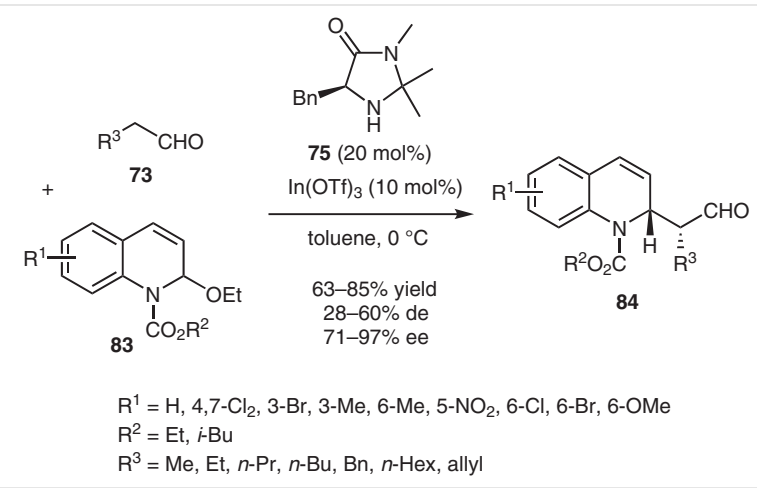

Scheme $22 \alpha$-Arylation of aldehydes with quinoline acetals 
low to moderate diastereoselectivities (28-60\% de), and good to excellent enantioselectivities (71-97\% ee). The presence of both electron-donating and electron-withdrawing groups $\left(\mathrm{R}^{1}\right)$ on the quinoline unit was compatible, providing the corresponding dihydroquinoline derivatives in high enantioselectivities. Moreover, different unfunctionalized aldehydes varying in chain length were well tolerated. The utility of the methodology was demonstrated by converting products into valuable tetrahydroquinolines, 2-substituted quinolines, and bridged quinoline derivatives.

Another type of dual catalysis was employed in 2013 by Ratovelomanana-Vidal, Michelet, and co-workers to promote the asymmetric cyclization of disubstituted formyl alkynes 85 into the corresponding chiral functionalized cyclopentanes $\mathbf{8 6} .{ }^{38}$ The organocatalyst was simple achiral cyclohexylamine and the Lewis acid and chiral indium complex derived from $20 \mathrm{~mol} \%$ of $\mathrm{InCl}_{3}$ and $22 \mathrm{~mol} \%$ of $(R)$-BINAM (Scheme 23). The reaction performed in benzene at $20{ }^{\circ} \mathrm{C}$ led to cyclic chiral products 86 in both moderate yields (25-48\%) and enantioselectivities (56-68\% ee). However, the authors demonstrated that replacing the indium catalyst by a chiral copper complex derived from 6 $\mathrm{mol} \%$ of $\mathrm{Cu}(\mathrm{OTf})_{2}$ and $7.5 \mathrm{~mol} \%$ of $(R)$-MeOBIPHEP allowed higher enantioselectivities to be reached ( $94 \%$ ee).

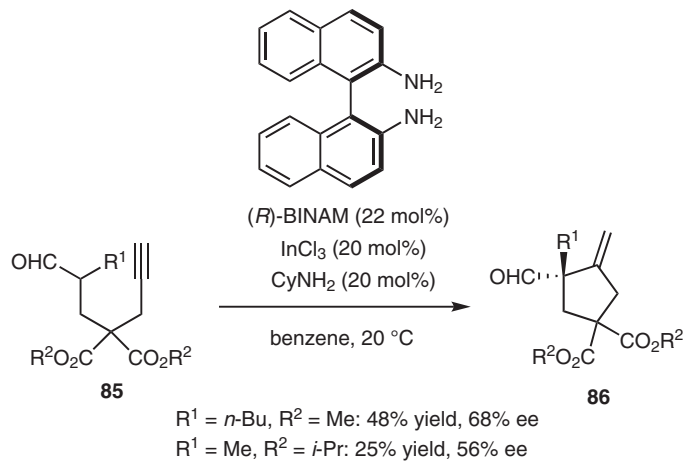

Scheme 23 Cyclization of disubstituted formyl alkynes

The vinylogous Mukaiyama aldol reaction, especially the $\gamma$-selective aldol process, is a key transformation since it provides $\delta$-hydroxy- $\alpha, \beta$-unsaturated carbonyl compounds which are attractive targets for medicinal chemistry. ${ }^{39}$ So far, most of chiral catalysts used in asymmetric vinylogous Mukaiyama aldol reactions of simple ester-derived dienol ethers are copper and titanium complexes. In 2015, Feng, Lin, and co-workers showed that a chiral indium catalyst generated in situ from $10 \mathrm{~mol} \%$ of $\operatorname{In}(\mathrm{OTf})_{3}$ and $20 \mathrm{~mol} \%$ of chiral $N, N^{\prime}$-dioxide 87 was able at $-20^{\circ} \mathrm{C}$ to highly efficiently promote the enantioselective vinylogous Mukaiyama aldol reaction of methyl crotonate derived silyl dienol ester $\mathbf{8 8}$ with aldehydes $\mathbf{3 4}$ to afford the corresponding chiral $\delta$ hydroxy- $\alpha, \beta$-unsaturated esters $\mathbf{8 9}$ in moderate to quantitative yields (45-99\%) and uniformly high ee values (82-98\% ee) (Scheme 24). ${ }^{40}$ The catalyst system was compatible with various aromatic aldehydes bearing either electron-withdrawing or electron-donating substituents at different positions on the phenyl ring (86-98\% ee). Generally, orthosubstituted aldehydes gave slightly lower yields and enantioselectivities than meta- and para-substituted ones. Ringcondensed 1-naphthaldehyde and heteroaromatic 2-furaldehyde were also suitable, affording the corresponding products in 96-99\% yield and 92-94\% ee. Interestingly, even aliphatic aldehydes were also tolerated, leading to the corresponding products with high ee values (83-98\% ee) albeit with generally lower yields (45-88\%) than aromatic aldehydes. The methodology was applied to the synthesis of natural bioactive products, such as $(R)-\delta$-decalactone, (3R,5R)-valerolactone, and $(4 R, 6 R, 10 R, 12 R)$-verbalactone.

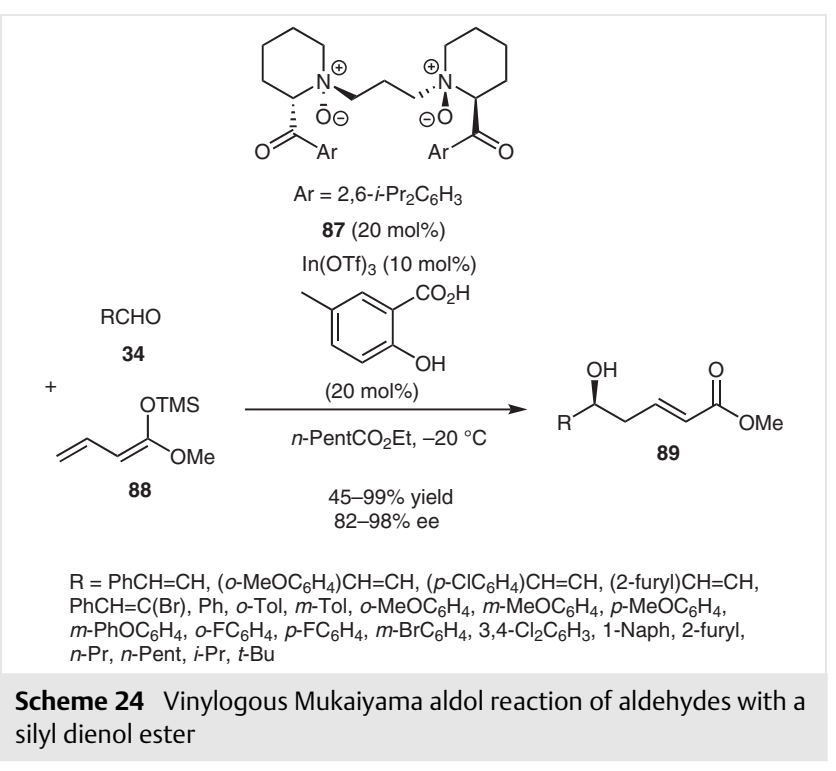

The asymmetric Mukaiyama-Michael reaction allows an easy access to enantioenriched 1,5-dicarbonyl compounds. In this context, in 2018 Singh and co-workers developed the enantioselective indium-catalyzed Mukaiyama-Michael addition of silyl enol ethers 90 to $\alpha, \beta$-unsaturated 2-acylimidazoles $91 .{ }^{41}$ The reaction occurred at $0{ }^{\circ} \mathrm{C}$ in chloroform as solvent in the presence of a chiral indium catalyst generated in situ from $10 \mathrm{~mol} \%$ of $\operatorname{In}(\mathrm{OTf})_{3}$ and 12 mol\% of chiral indapybox ligand ent-52. It resulted in the formation of chiral 1,5-dicarbonyl compounds 92 in generally high yields (76-92\%) and low to excellent enantioselectivities (18-94\% ee), as illustrated in Scheme 25. The catalyst system was compatible with a variety of aromatic $\alpha, \beta-$ unsaturated 2-acylimidazoles and silyl enol ethers, both exhibiting electron-withdrawing and electron-donating substituents on the phenyl groups. Very importantly, the authors found that by simply switching from indium to scandium $\left(\mathrm{Sc}(\mathrm{OTf})_{3}\right)$, the reaction afforded the enantiomeric products by using the same ligand. 


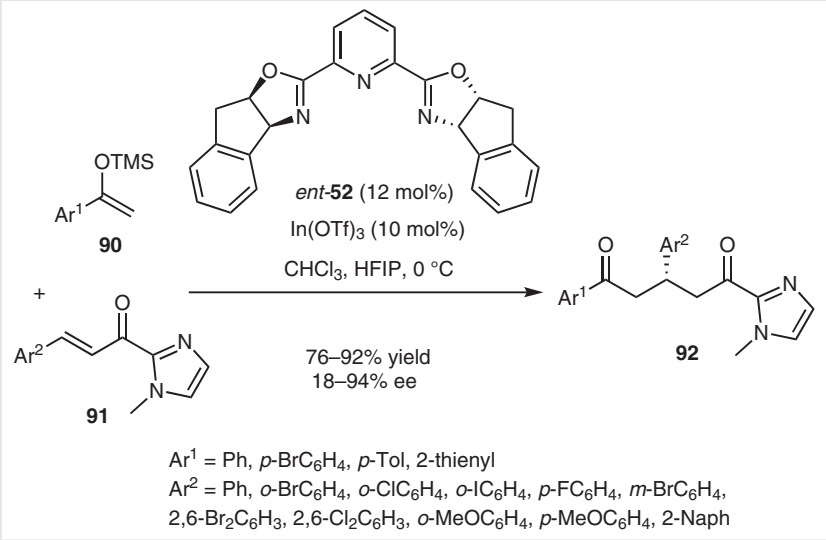

Scheme 25 Michael addition of silyl enol ethers to $\alpha, \beta$-unsaturated 2-acylimidazoles

\section{Domino and Tandem Reactions}

Domino and tandem processes allow very complex molecules to be synthesized in a single vessel without involving costly isolation and purification of intermediates. ${ }^{42}$ Among these one-pot reactions, domino processes are especially economic and convenient since they occur under strictly the same reaction conditions. ${ }^{43}$ As an example based on asymmetric indium catalysis, is the enantioselective domino redox isomerization/intramolecular Michael reaction of propargyl alcohols 93 reported in 2012 by the Trost group. ${ }^{44}$ Actually, this process was based on a multicatalysis, involving $3 \mathrm{~mol} \%$ of $\operatorname{In}(\mathrm{OTf})_{3}, 3 \mathrm{~mol} \%$ of (indenide) $\mathrm{Ru}\left(\mathrm{PPh}_{3}\right)_{2} \mathrm{Cl}$, and $30 \mathrm{~mol} \%$ of chiral cinchona alkaloid 94 as organocatalyst. It led to the corresponding chiral cycloalkanes 95 in low to excellent enantioselectivities (14$97 \%$ ee) and good yields (60-83\%), as presented in Scheme 26 . Chiral six-membered products $(n=2)$ were in most cases obtained with high ee values ( $84-97 \%$ ee) excepted in the reaction of a primary propargylic alcohol $(\mathrm{R}=\mathrm{H}: 14 \%$ ee). A low enantioselectivity ( $22 \%$ ee) was also obtained in the formation of a five-membered product $(n=1)$. A possible mechanism depicted in Scheme 26 proposed the conversion of propargyl alcohol 93 into the corresponding $\alpha, \beta$-unsaturated carbonyl compound 96 via 1,2-hydride migration promoted by ruthenium/indium catalysis. Then, a subsequent intramolecular Michael addition evolving through iminium catalysis in the presence of the cinchona alkaloid primary amine as organocatalyst generated carbocycle $\mathbf{A}$, which upon hydrolysis led to final ketone $\mathbf{9 5}$.

An asymmetric synthesis of tetrahydrocarbazoles was based in 2015 by Tang, Zhang, and co-workers on an enantioselective tandem ring-opening/Conia-ene cyclization reaction of alkynylindoles 97 with donor-acceptor cyclopropanes 98. ${ }^{45}$ The one-pot process was successively catalyzed by a chiral copper catalyst in situ generated from $10 \mathrm{~mol} \%$ of $\mathrm{Cu}(\mathrm{OTf})_{2}$ and $10 \mathrm{~mol} \%$ of chiral bisoxazoline ligand 99 in toluene at $40{ }^{\circ} \mathrm{C}$, and by $20 \mathrm{~mol} \%$ of $\mathrm{InCl}_{3}$ in the presence of
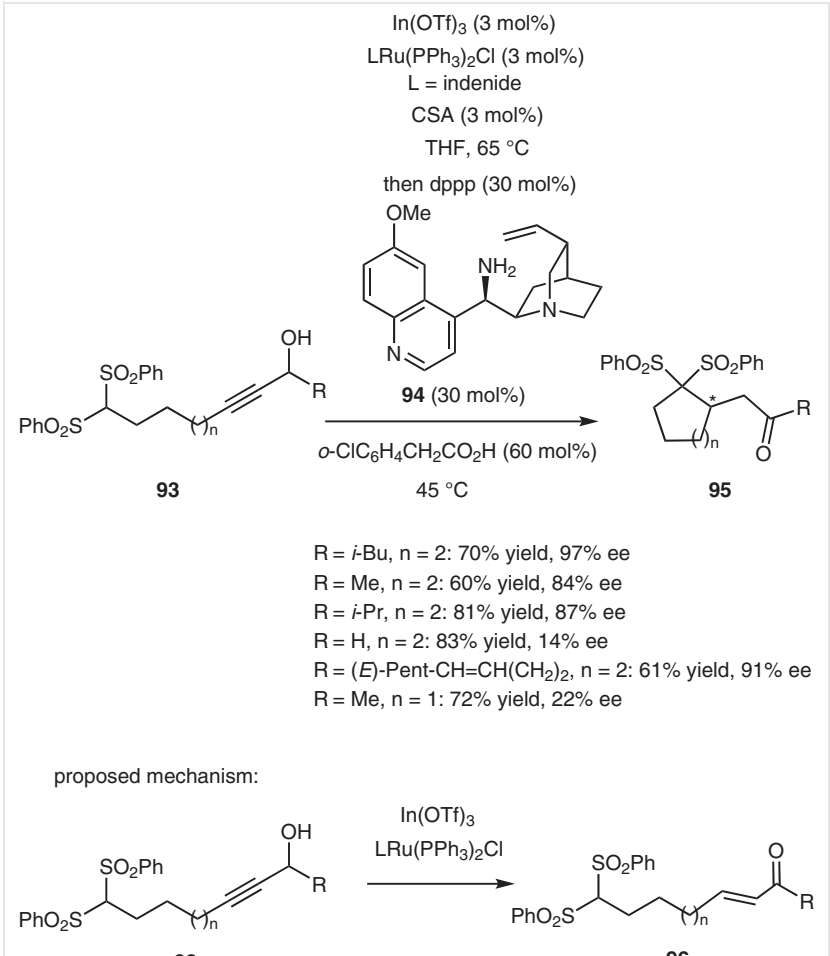

93

96
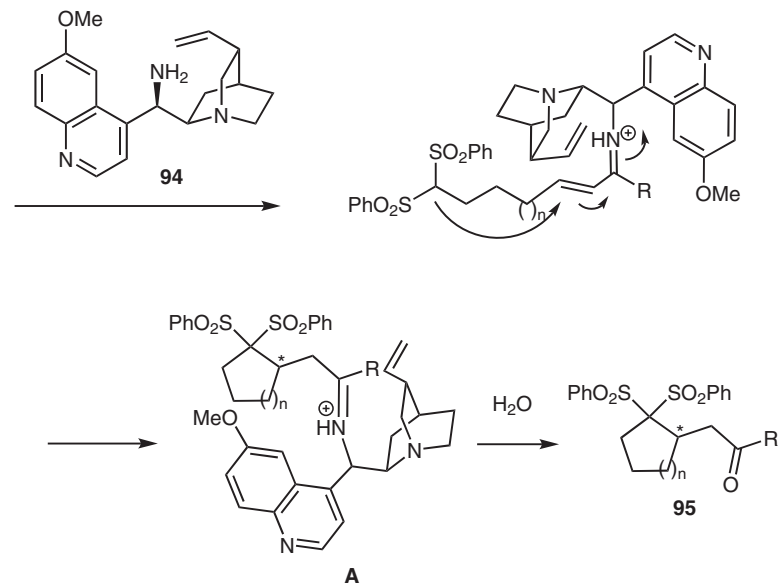

Scheme 26 Domino redox isomerization/intramolecular Michael reaction of propargyl alcohols

$10 \mathrm{~mol} \%$ of DBU at $120^{\circ} \mathrm{C}$ in the same solvent. As shown in Scheme 27, the copper-catalyzed asymmetric ring-opening reaction of cyclopropanes 98 with alkynylindoles 97 resulted in the formation of malonate intermediates $\mathbf{1 0 0}$ which further underwent a Conia-ene cyclization under indium catalysis to give the final chiral 1,2,3,4-tetrahydrocarbazoles 101 in good yields (63-87\%) and moderate to high enantioselectivities (57-94\% ee). The catalyst system tolerated the presence of various substituents on the phenyl ring of the indole substrates $\left(R^{1}\right)$ and a variety of donor-acceptor cyclopropanes were compatible. Even cyclopropanes bear- 
ing heterocyclic substituents, such as 2-furyl and 2-thienyl groups, provided the corresponding products in good yields (68-71\%) albeit with moderate enantioselectivities (57$77 \%$ ee).

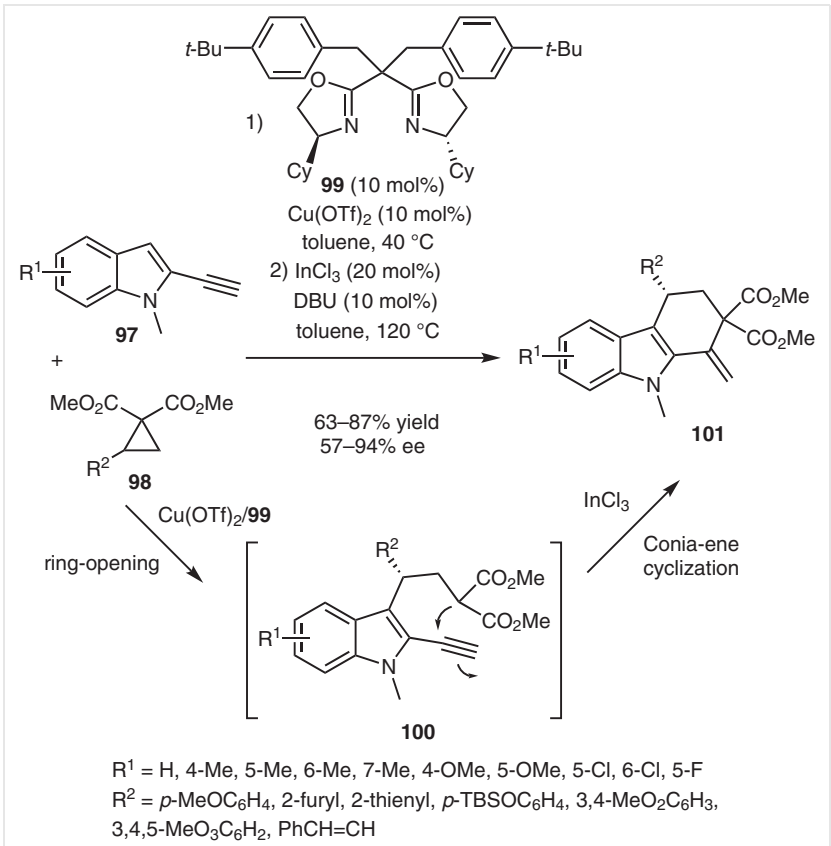

Scheme 27 Tandem ring-opening/Conia-ene cyclization reaction of alkynylindoles with donor-acceptor cyclopropanes

In 2017, Luo, Lv, and Zhong developed the enantioselective indium-catalyzed domino Michael/cyclization reaction of $\beta, \gamma$-unsaturated $\alpha$-keto esters $\mathbf{4 4}$ with diazo esters 102 (Scheme 28). ${ }^{46}$ The reaction was promoted at room temperature by a combination of $5 \mathrm{~mol} \%$ of $\mathrm{InBr}_{3}$ and the same quantity of chiral calcium phosphate $\mathbf{1 0 3}$ in DCE as solvent, delivering the corresponding functionalized chiral cyclo-

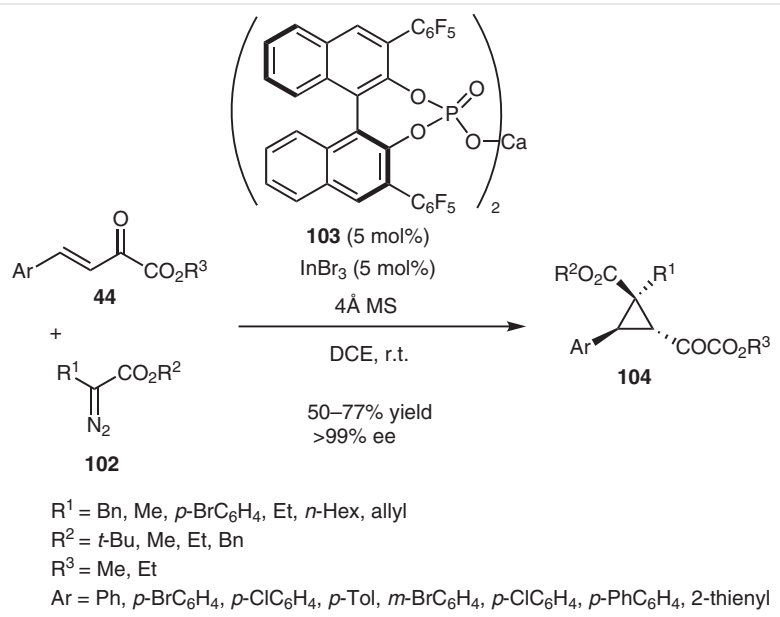

Scheme 28 Domino Michael/cyclization reaction of aromatic $\beta, \gamma$-unsaturated $\alpha$-keto esters with aliphatic diazo esters propanes 104 as single diastereo- and enantiomers ( $>99 \%$ ee) in moderate to good yields (50-77\%). The presence of different ester groups on both diazo esters $\left(\mathrm{R}^{2}\right)$ and $\beta, \gamma$-unsaturated $\alpha$-keto esters $\left(\mathrm{R}^{3}\right)$ were well tolerated, providing similar excellent results. Only aliphatic diazo esters were compatible while no reaction occurred with an aromatic diazo ester $\left(\mathrm{R}^{1}=\mathrm{Ph}\right)$. A number of aromatic $\beta, \gamma$-unsaturated $\alpha$-keto esters bearing either electron-withdrawing or electron-donating groups could be equally applied with comparable enantioselectivity. Even an heteroaromatic $\beta, \gamma$-unsaturated $\alpha$-keto ester ( $\mathrm{Ar}=2$-thienyl) delivered the corresponding cyclopropane with $67 \%$ yield and $>99 \%$ ee. In contrast, an aliphatic $\beta, \gamma$-unsaturated $\alpha$-keto esters (Me instead of $\mathrm{Ar}$ ) underwent the reaction with both low yield (33\%) and enantioselectivity (18\% ee).

The importance of indane scaffolds in medicinal chemistry is well known. ${ }^{47}$ In this context, in 2017 the Enders group disclosed a novel route to chiral methyleneindanes based on an enantioselective tandem Michael/Conia-ene cyclization reaction of 2-ethynyl- $\beta$-nitrostyrenes 105 with malonates 106 (Scheme 29). ${ }^{48}$ The first step of the sequence, consisting of the Michael addition of the malonates to the nitrostyrenes, was organocatalyzed at room temperature by only $0.5-5 \mathrm{~mol} \%$ of chiral squaramide 107 in dichloromethane as solvent to give intermediates 108. In a second step, the latter underwent a Conia-ene cyclization catalyzed by $10 \mathrm{~mol} \%$ of $\operatorname{In}(\mathrm{OTf})_{3}$ in toluene at $80^{\circ} \mathrm{C}$, which resulted in the formation of the corresponding chiral methyleneindanes 109 in variable yields (14-98\%) and good to

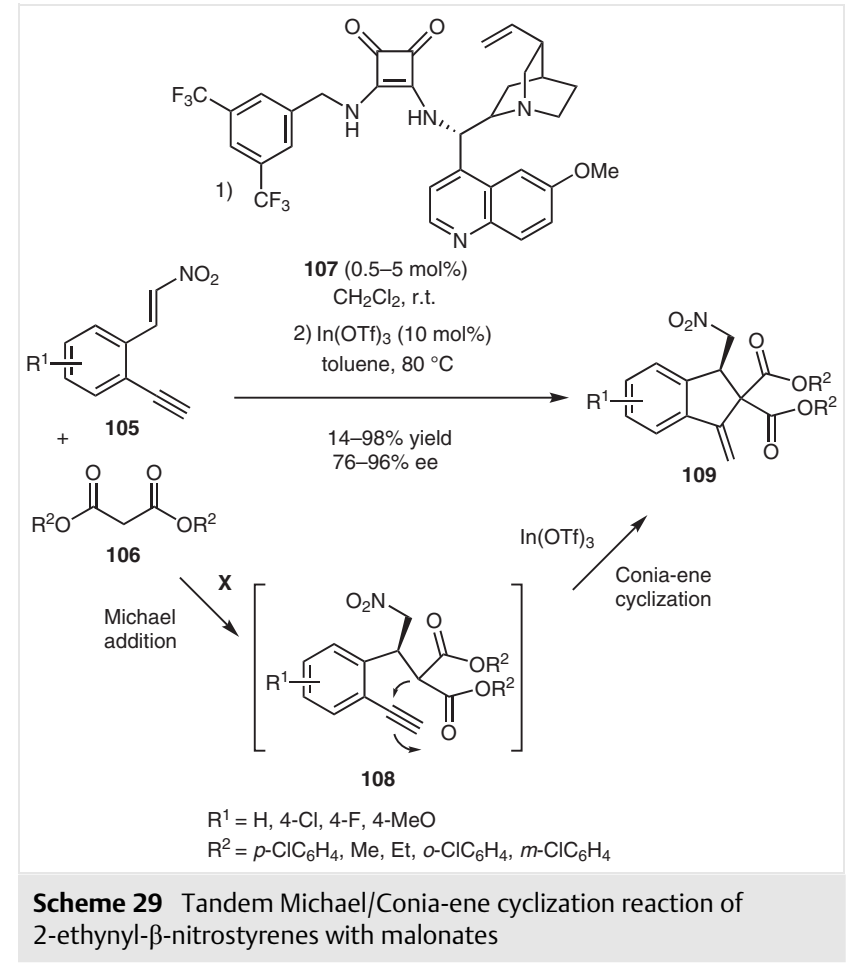


excellent enantioselectivities (76-96\% ee). Generally, alkyl malonates reacted with better enantioselectivities (82-96\% ee) than aryl ones (76-86\% ee).

In 2018, Feng and co-workers described the first example of asymmetric domino insertion/Claisen rearrangement reaction of $\mathrm{N}$-sulfonyl-1,2,3-triazoles $\mathbf{1 1 0}$ with allylic alcohol esters 111, which was based on a bimetallic relay catalytic system involving an achiral rhodium complex and a chiral indium catalyst (Scheme 30).$^{49}$ Indeed, in the presence of $1.25 \mathrm{~mol} \%$ of $\mathrm{Rh}_{2}(\mathrm{esp})_{2}, 2 \mathrm{~mol} \%$ of $\operatorname{In}(\mathrm{OTf})_{3}$, and 2 mol\% of chiral $N, N^{\prime}$-dioxide ligand 112, the transformation afforded a range of chiral $\alpha$-vinylated- $\gamma$-oxo- $\beta$-amino esters 113 in good to quantitative yields (60-99\%) and good to excellent diastereo- (70->90\% de) and enantioselectivities (66-96\% ee). Several allylic alcohols were tolerated, affording the corresponding products in generally excellent stereoselectivities. Regardless of the steric hindrance of the ester groups, all the allylic alcohol esters provided comparable excellent enantioselectivities whereas the diastereoselectivities decreased gradually from methyl ester to tert-butyl ester $\left(90 \%\right.$ de for $\mathrm{R}^{3}=\mathrm{OMe}, 80 \%$ de for $\mathrm{R}^{3}=\mathrm{O} i$-Pr, and $70 \%$ de for $\mathrm{R}^{3}=\mathrm{O} t-\mathrm{Bu}$ ). Moreover, a range of 1-tosyl-substituted 1,2,3-triazoles exhibiting electronically diverse aryl groups $\left(R^{1}\right)$ smoothly underwent the reaction with excellent enantio- and diastereoselectivities while the reaction of an aliphatic sulfonyl group $\left(\mathrm{R}^{2}=\mathrm{Me}\right)$ provided a lower enantioselectivity (66\% ee). Even an allylic alcohol bearing a benzoyl group $\left(\mathrm{R}^{3}=\mathrm{Ph}\right)$ was also suitable for the catalyst system, since it afforded the corresponding 1,4-diketone in good yield (74\%) and diastereo- and enantioselectivities (74\% de and $88 \%$ ee). A mechanism based on a dual relay catalysis is depicted in Scheme 30. In the presence of the achiral rhodium catalyst, $\mathrm{Rh}(\mathrm{II})$-bound imino carbene intermediate $\mathbf{B}$ was generated. Then, $\mathrm{O}$-insertion of the allylic alcohol into the latter led to zwitterionic intermediate $\mathbf{C}$. Through a subsequent proton transfer and release of $\mathrm{Rh}(\mathrm{II})$ catalyst, $(Z)-$
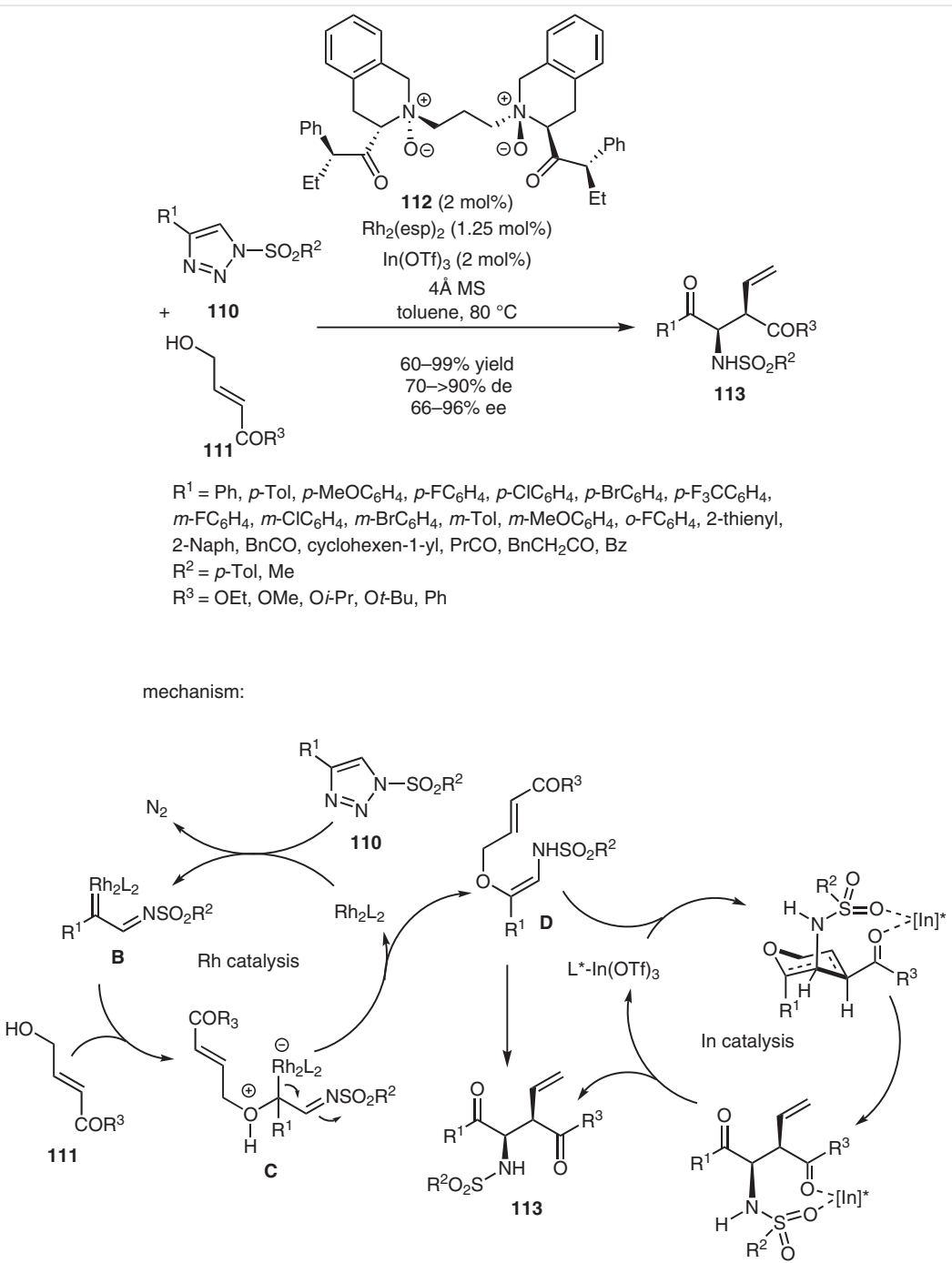

Scheme 30 Domino insertion/Claisen rearrangement reaction of $N$-sulfonyl-1,2,3-triazoles with allylic alcohol esters 
allylic vinyl ether intermediate D was generated, which subsequently underwent an asymmetric Claisen rearrangement in the presence of the chiral indium catalyst to give the final product.

Another type of allylic alcohol esters, such as MoritaBaylis-Hillman reagents 114, was also investigated in these reactions. ${ }^{49}$ In this case, the optimal catalyst system was composed of $5 \mathrm{~mol} \%$ of In(OTf $)_{3}, 1.25 \mathrm{~mol} \%$ of $\mathrm{Rh}_{2}(\mathrm{esp})_{2}$, and 5 mol\% of a related chiral $N, N^{\prime}$-dioxide ligand 115 in toluene at $50{ }^{\circ} \mathrm{C}$ (Scheme 31). Under these optimized conditions, the reaction of Morita-Baylis-Hillman reagents 114 with $\mathrm{N}$-tosyl-1,2,3-triazoles $\mathbf{1 1 0}$ afforded the corresponding chiral $\delta$-oxo- $\gamma$-amino esters $\mathbf{1 1 6}$ in good to quantitative yields (61-99\%) and good to high ee values (56-88\% ee). It was found that the electronic nature of the aryl groups $\left(R^{1}\right)$ at the $N$-tosyl-1,2,3-triazoles had a limited effect on the results. The lowest enantioselectivities (56-72\% ee) were obtained in the reaction of $n$-propyl- and benzyl-substituted 1,2,3-triazoles.

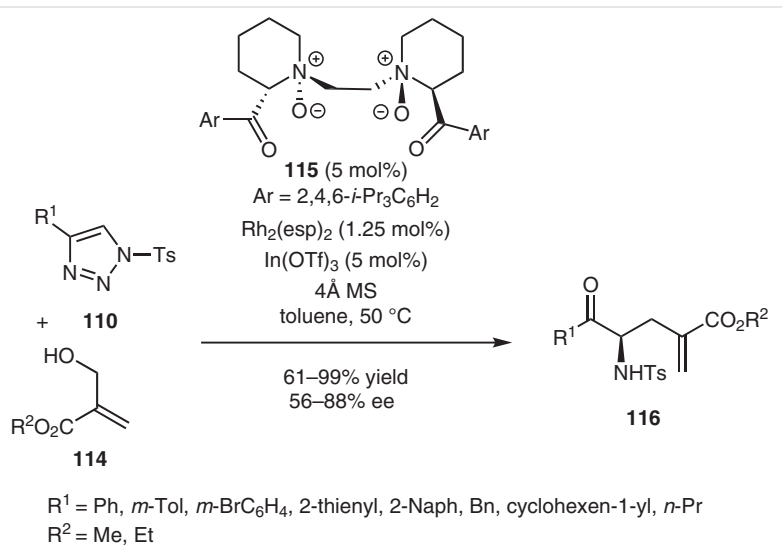

Scheme 31 Domino insertion/Claisen rearrangement reaction of $\mathrm{N}$-tosyl-1,2,3-triazoles with Morita-Baylis-Hillman reagents

\section{Conclusion}

As a less toxic, more stable, and more air- and water-tolerant metal, indium has gained a significant importance in green catalysis. While underestimated for a long time, indium catalysts are now more frequently applied to promote all types of transformations. Especially, a spectacular development of highly enantioselective indium-catalyzed reactions has emerged in the last decade. This review updates this field since the beginning of 2012, demonstrating that asymmetric indium catalysis has a bright future. The diversity of the chiral indium complexes employed reflects that of the asymmetric reactions successfully developed, including allylations, propargylations, allenylations, cycloadditions, cyclizations, alkylations of aldehydes, aldol condensations, Michael additions, $\mathrm{S}_{\mathrm{N}} 1$ reactions and, tandem and domino reactions among other reactions. In these generally very highly enantioselective processes, a wide variety of chiral ligands have been already successfully chelated to indium, such as bisoxazolines, oxazolines, bisimidazolines, imidazolines, imidazolidinones, $N, N^{\prime}$-dioxides, 1,2-amino alcohols, BINOL derivatives, 1,4-diamines such as BINAM, cinchona alkaloids, bishydroxamic acids, and phosphoric acids, among others. For example, various indium(III) chiral catalysts have allowed the first highly enantioselective allylations of isatins and acyclic $\alpha$-keto esters with functionalized $\beta$-carbonyl allylstannanes with $99 \%$ ee; allylation of $\mathrm{N}$-aryl-isatimines with allyltributyltin with $97 \%$ ee; and amide allylation of $\alpha$-iminoamides with $N$-substituted $\beta$ amido allylstannanes with $96 \%$ ee to be achieved. More rarely employed indium(I) chiral complexes also gave excellent ee values in allylations, such as that of (hetero)aromatic hydrazones and $\mathrm{N}, \mathrm{O}$-aminals with allyl pinacol boronate ( $96 \%$ ee). In addition, the first propargylation of aldehydes with stannylated allenyl amides was achieved with $96 \%$ ee. In the area of cycloadditions, the first hetero-Diels-Alder cycloaddition of $\beta, \gamma$-unsaturated $\alpha$-keto esters with disubstituted cyclopentadienes was regioselectively performed with $>99 \%$ ee. Similar ee values were described in the first indium-catalyzed hetero-Diels-Alder cycloaddition of allenes with $\alpha, \beta$-unsaturated conjugated compounds as well as in the first catalytic hetero-Diels-Alder reaction of $\beta, \gamma$ unsaturated $\alpha$-keto esters with alkoxyallenes. Very good results (99\% ee) were also disclosed for 1,3-dipolar cycloaddition between nitrones and $\alpha, \beta$-unsaturated 7-azaindoline amides and in intermolecular carbonyl-ene reaction between trisubstituted alkenes and glyoxylates. Many other types of transformations catalyzed by indium(III) chiral complexes also provided remarkable ee values, such as ringopening reactions of aromatic meso-epoxides with aromatic amines (99\% ee); $\alpha$-alkylation/allylation/alkylation reactions of aliphatic aldehydes with benzylic (96\% ee), allylic ( $90 \%$ ee), and propargylic ( $98 \%$ ee) alcohols; $\alpha$-arylation of aldehydes with quinoline acetals ( $97 \%$ ee); vinylogous $\mathrm{Mu}-$ kaiyama aldol reaction of methyl crotonate derived silyl dienol ester with aldehydes ( $98 \%$ ee); Mukaiyama Michael addition of silyl enol ethers to $\alpha, \beta$-unsaturated 2-acylimidazoles ( $94 \%$ ee); and domino Michael/cyclization reaction of $\beta, \gamma$-unsaturated $\alpha$-keto esters with diazo esters (>99\% ee). Moreover, multicatalysis, combining an indium catalyst with either another metal, such as rhodium, copper, or ruthenium, or an organocatalyst, has generated promising results in domino and tandem reactions. For example, enantioselectivities of $97 \%$ ee were achieved in a domino redox isomerization/intramolecular Michael reaction of propargyl alcohols to afford chiral cycloalkanes catalyzed by a combination of indium-, ruthenium-, and organocatalysts. Moreover, a novel route to chiral methyleneindanes was based on an enantioselective tandem Michael/Conia-ene cyclization reaction of 2-ethynyl- $\beta$-nitrostyrenes with malonates catalyzed by a combination of organo- and indium catalysts with $96 \%$ ee. An asymmetric tandem ring-opening/Coniaene cyclization reaction of alkynylindoles with donor- 
acceptor cyclopropanes was successively catalyzed by a dual copper/indium catalyst system to give 1,2,3,4-tetrahydrocarbazoles with $94 \%$ ee. Another dual metal catalysis based on indium and rhodium was used to promote the first asymmetric domino insertion/Claisen rearrangement reaction of $N$-sulfonyl-1,2,3-triazoles with allylic alcohol esters, giving rise to $\alpha$-vinylated- $\gamma$-oxo- $\beta$-amino esters with $96 \%$ ee.

The stability and low toxicity of indium makes indium catalysis suit the growing demand for more environmentally benign processes and offers a real opportunity to replace other toxic and expensive metals in the near future. This review demonstrates that indium brings a novel potential for green catalysis and that this original field is growing very rapidly. Even if remarkable results have already been described, challenges remain, such as the use of indium in more multicatalyzed processes, especially those based on the combination of indium with organocatalysts. Moreover, more applications in the total synthesis of important biologically active and natural products are needed.

(1) Chao, L.-C.; Rieke, R. D. J. Org. Chem. 1975, 40, 2253.

(2) Araki, S.; Ito, H.; Butsugan, Y. J. Org. Chem. 1988, 53, 1831.

(3) Li, Y.; Xu, M.-H. In Indium: Properties, Technological Applications and Health Issues; Woo, H. G.; Choi, H. T., Ed.; Nova Science: New York, 2013, 187-217.

(4) (a) Podlech, J.; Maier, T. C. Synthesis 2003, 633. (b) Frost, C. G.; Hartley, J. P. Mini-Rev. Org. Chem. 2004, 1, 1. (c) Araki, S.; Hirashita, T. In Main Group Metals in Organic Synthesis; Yamamoto, H.; Oshima, K., Ed.; Wiley-VCH: Weinheim, 2004, 323-386. (d) Ghosh, R.; Maiti, S. J. Mol. Catal.: A 2007, 264, 1.

(5) (a) Cintas, P. Synlett 1995, 1087. (b) Li, C.-J.; Chan, T.-H. Tetrahedron 1999, 55, 11149. (c) Ranu, B. C. Eur. J. Org. Chem. 2000, 2347. (d) Nair, V.; Ros, S.; Jayan, C. N.; Pillai, B. S. Tetrahedron 2004, 60, 1959. (e) Augé, J.; Lubin-Germain, N.; Uziel, J. Synthesis 2007, 1739 .

(6) Yang, Y.-S.; Wang, S.-W.; Long, Y. Curr. Org. Chem. 2016, 20, 2865.

(7) (a) Roy, U. K.; Roy, S. Chem. Rev. 2010, 110, 2472. (b) Shen, Z.-L.; Wang, S.-Y.; Chok, Y.-K.; Xu, Y.-H.; Loh, T.-P. Chem. Rev. 2013, 113, 271.

(8) (a) Yamamoto, Y.; Asao, N. Chem. Rev. 1993, 93, 2207. (b) Yus, M.; González-Gómez, J. C.; Foubelo, F. Chem. Rev. 2011, 111, 7774. (c) Yus, M.; González-Gómez, J. C.; Foubelo, F. Chem. Rev. 2013, 113, 5595. (d) Lumbroso, A.; Cooke, M. L.; Breit, B. Angew. Chem. Int. Ed. 2013, 52, 1890. (e) Huo, H.; Duvall, J. R.; Huang, M.-Y.; Hong, R. Org. Chem. Front. 2014, 1, 303.

(9) Kargbo, R.; Cook, G. R. Curr. Org. Chem. 2007, 11, 1287.

(10) Loh, T.-P.; Zhou, J.-R.; Li, X.-R. Tetrahedron Lett. 1999, 40, 9333.

(11) Cook, G. R.; Kargbo, R.; Maity, B. Org. Lett. 2005, 7, 2767.

(12) (a) Murata, Y.; Takahashi, M.; Yagishita, F.; Sakamoto, M.; Sengoku, T.; Yoda, H. Org. Lett. 2013, 15, 6182. (b) Takahashi, M.; Murata, Y.; Yagishita, F.; Sakamoto, F.; Sengoku, T.; Yoda, H. Chem. Eur. J. 2014, 20, 11091.

(13) Kitson, R. A.; Millemaggi, A.; Taylor, R. J. K. Angew. Chem. Int. Ed. 2009, 48, 9426 .
(14) Takahashi, M.; Murata, Y.; Ishida, M.; Yagishita, F.; Sakamoto, M.; Sengokua, T.; Yoda, H. Org. Biomol. Chem. 2014, 12, 7686.

(15) Nakamura, S.; Hara, Y.; Furukawa, T.; Hirashita, T. RSC Adv. 2017, 7, 15582.

(16) (a) Chakrabarti, A.; Konishi, H.; Yamaguchi, M.; Schneider, U.; Kobayashi, S. Angew. Chem. Int. Ed. 2010, 49, 1838. (b) Huang, Y.Y.; Chakrabarti, A.; Morita, N.; Schneider, U.; Kobayashi, S. Angew. Chem. Int. Ed. 2011, 50, 11121.

(17) Schneider, U.; Kobayashi, S. Acc. Chem. Res. 2012, 45, 1331.

(18) Chen, T.; Cai, C. Org. Biomol. Chem. 2016, 14, 5019.

(19) Kumar, D.; Vemula, S. R.; Balasubramanian, N.; Cook, G. R. Acc. Chem. Res. 2016, 49, 2169.

(20) Sengoku, T.; Kokubo, K.; Sakamoto, M.; Takahashi, M.; Yoda, H. Org. Biomol. Chem. 2017, 15, 320.

(21) Loh, T.-P.; Lin, M.-J.; Tan, K.-L. Tetrahedron Lett. 2003, 44, 507.

(22) Haddad, T. D.; Hirayama, L. C.; Buckley, J. J.; Singaram, B. J. Org. Chem. 2012, 77, 889.

(23) Sengoku, T.; Ikeda, I.; Ai, K.; Takahashi, M.; Yoda, H. Org. Biomol. Chem. 2019, 17, 2614.

(24) Ali, T.; Chauhan, K. K.; Frost, C. G. Tetrahedron Lett. 1999, 40, 5621.

(25) Lv, J.; Zhang, L.; Hu, S.; Cheng, J.-P.; Luo, S. Chem. Eur. J. 2012, 18, 799.

(26) Zhao, B.; Loh, T.-P. Org. Lett. 2013, 15, 2914.

(27) Heravi, M. M.; Ahmadi, T.; Ghavidel, M.; Heidari, B.; Hamidi, H. RSC Adv. 2015, 5, 101999.

(28) Wang, L.; Lv, J.; Zhang, L.; Luo, S. Angew. Chem. Int. Ed. 2017, 56, 10867.

(29) Li, S.; Lv, J.; Luo, S. Org. Chem. Front. 2018, 5, 1787.

(30) (a) Gothelf, K. V.; Jørgensen, K. A. Chem. Rev. 1998, 98, 863. (b) Pellissier, H. Tetrahedron 2007, 63, 3235. (c) Stanley, L. M.; Sibi, M. P. Chem. Rev. 2008, 108, 2887. (d) Kissane, M.; Maguire, A. R. Chem. Soc. Rev. 2010, 39, 845. (e) Hashimoto, T.; Maruoka, K. Chem. Rev. 2015, 115, 5366. (f) Singh, M. S.; Chowdhury, S.; Koley, S. Tetrahedron 2016, 72, 1603. (g) Klier, L.; Tur, F.; Poulsen, P. H.; Jørgensen, K. A. Chem. Soc. Rev. 2017, 46, 1080.

(31) Zhang, M.; Kumagai, N.; Shibasaki, M. Chem. Eur. J. 2017, 23, 12450.

(32) Clarke, M. L.; France, M. B. Tetrahedron 2008, 64, 9003.

(33) Zhang, X.; Wang, M.; Ding, R.; Xu, Y.-H.; Loh, T.-P. Org. Lett. 2015, 17, 2736.

(34) Gao, B.; Xie, M.; Sun, A.; Hu, X.; Ding, X.; Liu, X.; Lin, L.; Feng, X. Adv. Synth. Catal. 2012, 354, 1509.

(35) Capdevila, M. G.; Emer, E.; Benfatti, F.; Gualandi, A.; Wilson, C. M.; Cozzi, P. G. Asian J. Org. Chem. 2012, 1, 38.

(36) Gualandi, A.; Mengozzi, L.; Wilson, C. M.; Cozzi, P. G. Synthesis 2014, 46, 1321.

(37) Volla, C. M. R.; Fava, E.; Atodiresei, I.; Rueping, M. Chem. Commun. 2015, 51, 15788.

(38) Praveen, C.; Montaignac, B.; Vitale, M. R.; RatovelomananaVidal, V.; Michelet, V. ChemCatChem 2013, 5, 2395.

(39) Casiraghi, G.; Battistini, L.; Curti, C.; Rassu, G.; Zanardi, F. Chem. Rev. 2011, 111, 3076.

(40) Fu, K.; Zheng, J.; Lin, L.; Liu, X.; Feng, X. Chem. Commun. 2015 , $51,3106$.

(41) Rout, S.; Das, A.; Singh, V. K. J. Org. Chem. 2018, 83, 5058.

(42) (a) Ho, T.-L. Tandem Organic Reactions 1992. (b) Bunce, R. A. Tetrahedron 1995, 51, 13103. (c) Padwa, A.; Weingarten, M. D. Chem. Rev. 1996, 96, 223. (d) Denmark, S. E.; Thorarensen, A. Chem. Rev. 1996, 96, 137. (e) Hulme, C.; Gore, V. Curr. Med. Chem. 2003, 10, 51. (f) Tietze, L. F.; Rackelmann, N. Pure Appl. Chem. 2004, 76, 1967. (g) Fogg, D. E.; dos Santos, E. N. Coord. Chem. Rev. 2004, 248, 2365. (h) Wasilke, J.-C.; Obrey, S. J.; Baker, 
R. T.; Bazan, G. C. Chem. Rev. 2005, 105, 1001. (i) Nicolaou, K. C.; Edmonds, D. J.; Bulger, P. G. Angew. Chem. Int. Ed. 2006, 45, 7134. (j) Chapman, C. J.; Frost, C. G. Synthesis 2007, 1. (k) Padwa, A.; Bur, S. K. Tetrahedron 2007, 63, 5341. (l) D'Souza, D. M.; Müller, T. J. J. Chem. Soc. Rev. 2007, 36, 1095. (m) Alba, A.-N.; Companyo, X.; Viciano, M.; Rios, R. Curr. Org. Chem. 2009, 13, 1432. (n) Themed collection on Rapid Complexity Generation in Natural Product Total Synthesis: Davies, H. M. L.; Sorensen, E. J. Eds. Chem. Soc. Rev. 2009, 38, 2981-3272. (o) Nicolaou, K. C.; Chen, J. S. Chem. Soc. Rev. 2009, 38, 2993. (p) Ruiz, M.; LopezAlvarado, P.; Giorgi, G.; Menéndez, J. C. Chem. Soc. Rev. 2011, 40, 3445. (q) De Graaff, C.; Ruijter, E.; Orru, R. V. A. Chem. Soc. Rev. 2012, 41, 3969. (r) Ardkhean, R.; Caputo, D. F. J.; Morrow, S. M.; Shi, H.; Xiong, Y.; Anderson, E. A. Chem. Soc. Rev. 2016, 45, 1557. (s) Hayashi, Y. Chem. Sci. 2016, 7, 866.

(43) (a) Posner, G. H. Chem. Rev. 1986, 86, 831. (b) Tietze, L. F.; Beifuss, U. Angew. Chem., Int. Ed. Engl. 1993, 32, 131. (c) Tietze, L. F. Chem. Rev. 1996, 96, 115. (d) Parsons, P. J.; Penkett, C. S.; Shell, A. J. Chem. Rev. 1996, 96, 195. (e) Dalko, P. I.; Moisan, L. Angew. Chem. Int. Ed. 2004, 43, 5138. (f) Ramon, D. J.; Yus, M. Angew. Chem. Int. Ed. 2005, 44, 1602. (g) Multicomponent Reactions; Zhu, J.; Bienaymé, H., Ed.; Wiley-VCH: Weinheim, 2005. (h) Tietze, L. F.; Brasche, G.; Gericke, K. Domino Reactions in Organic Synthesis; Wiley-VCH: Weinheim, 2006. (i) Pellissier, H. Tetrahedron 2006, 62, 2143. (j) Pellissier, H. Tetrahedron 2006, 62, 1619. (k) Enders, D.; Grondal, C.; Hüttl, M. R. M. Angew. Chem. Int. Ed. 2007, 46, 1570. (1) Guillena, G.; Ramon, D. J.; Yus, M. Tetrahedron: Asymmetry 2007, 18, 693. (m) Touré, B. B.; Hall, D. G. Chem. Rev. 2009, 109, 4439. (n) Synthesis of Heterocycles via Multicomponent Reactions I, In Topics in Heterocyclic Chemistry, Vol. 23; Orru, R. V. A.; Ruijter, E., Ed.; Springer: Berlin, 2010. (o) Synthesis of Heterocycles via Multicomponent Reactions II, In Topics in Heterocyclic Chemistry, Vol. 25; Orru, R. V. A.; Ruijter, E., Ed.; Springer: Berlin, 2010. (p) Pellissier, H. Adv. Synth. Catal. 2012, 354, 237. (q) Clavier, H.; Pellissier, H. Adv. Synth. Catal. 2012, 354, 3347. (r) Pellissier, H. Chem. Rev. 2013, 113, 442. (s) Pellissier, H. Asymmetric Domino Reactions; RSC: Cambridge, 2013. (t) Domino Reactions: Concepts for Efficient Organic Synthesis; Tietze, L. F., Ed.; Wiley-VCH: Weinheim, 2014. (u) Multicomponent Reactions in Organic Synthesis; Zhu, J.; Wang, Q.; Wang, M., Ed.; Wiley-VCH: Weinheim, 2014. (v) Multicomponent Reactions: Concepts and Applications for Design and Synthesis; Herrera, R. P.; Marqués-López, E., Ed.; Wiley: Hoboken, 2015. (w) Snyder, S. A. Science of Synthesis: Applications of Domino Transformations in Organic Synthesis; Georg Thieme Verlag: Stuttgart, 2016. (x) Pellissier, H. Adv. Synth. Catal. 2016, 358, 2194. (y) Pellissier, H. Adv. Synth. Catal. 2019, 361, 1733.

(44) Trost, B. M.; Breder, A.; Kai, B. Org. Lett. 2012, 14, 1708.

(45) Liu, Q.-J.; Yan, W. G.; Wang, L.; Zhang, X. P.; Tang, Y. Org. Lett. 2015, 17, 4014.

(46) Zhong, X.; Lv, J.; Luo, S. Org. Lett. 2017, 19, 3331.

(47) Vilums, M.; Heuberger, J.; Heitman, L. H.; Ijzerman, A. P. Med. Res. Rev. 2015, 35, 1097.

(48) Phillips, A. R.; Blümel, M.; Dochain, S.; Hack, D.; Enders, D. Synthesis 2017, 49, 1538.

(49) Chen, Y.; Dong, S.; Xu, X.; Liu, X.; Feng, X. Angew. Chem. Int. Ed. 2018, 57, 16554. 